Article

\title{
Supplier Selection in the Nuclear Power Industry with an Integrated ANP-TODIM Method under Z-Number Circumstances
}

\author{
Ya-Hua Liu ${ }^{1}$, Heng-Ming Peng ${ }^{2, *} \mathbb{C}$, Tie-Li Wang ${ }^{1, *}$, Xiao-Kang Wang ${ }^{3}$ and Jian-Qiang Wang ${ }^{3}$ \\ 1 School of Resources, Environment and Safety Engineering, University of South China, \\ Hengyang 421001, China; Petrelli1007@163.com \\ 2 School of Economics Management and Law, University of South China, Hengyang 421001, China \\ 3 School of Business, Central South University, Changsha 410083, China; xkwang@csu.edu.cn (X.-K.W.); \\ jqwang@csu.edu.cn (J.-Q.W.) \\ * Correspondence: hm_Pengjust@163.com (H.-M.P.); wangtieli@usc.edu.cn (T.-L.W.)
}

Received: 31 July 2020; Accepted: 11 August 2020; Published: 14 August 2020

\begin{abstract}
Under the double pressure of global energy consumption and climate change, nuclear power has become a low-carbon alternative energy source that could transform the energy structure of the globe. In the nuclear power industry, selecting suitable suppliers plays a significant role in improving the overall performance of nuclear power projects. Along with this symmetrical impact, this paper aims to develop a multistage decision-support framework to determine the optimal nuclear power equipment supplier, which is constructed in the context of Z-number information. Concretely, the Analytic Network Process (ANP) and Tomada de Decisão Iterativa Multicritério (TODIM) are extended by Z-numbers symmetrically-namely, Z-ANP and Z-TODIM. Z-ANP is first applied to analyze the symmetrical interdependence of criteria, so as to accurately determine the criterion weights. Further, the ranking of alternatives is obtained by Z-TODIM, which sufficiently considers the risk preference and psychological states of decision-makers. Finally, a practical case of nuclear-grade cable procurement in the Karachi 2-3 international nuclear power project is performed to illustrate the practicality of the proposed method, and its robustness and superiority are proven by comparing it with current representative approaches.
\end{abstract}

Keywords: nuclear power equipment; supplier selection; Z-numbers; ANP; TODIM; MCDM

\section{Introduction}

Faced with increasing environmental pollution and global warming, nuclear power is still one of the main options for most countries to cope with global energy shortages and climate change [1]. According to the International Atomic Energy Agency (IAEA) statistics, as of July 2020 there are 441 nuclear reactors in operation worldwide, with a capacity of 390,113 MWe. Over the past five years, the total amount of electricity supplied from the world's reactors has increased by more than 121.42 TW.h, effectively alleviating the pressure on resources and the environment [2]. With the flourishing development of Nuclear Power Plants (NPPs) worldwide, nuclear energy technology exports and international cooperation in nuclear power projects have become more frequent.

Since 1955, nuclear power in China has developed well and progressed over a long period. The success of the Hualong One nuclear power technology marks a firm step in the localization of nuclear power equipment and technology, which has effectively promoted the overall improvement of China's nuclear power industry capability. In recent years, China's nuclear power industry has been expanding, prompting massive exports of technologies and equipment [3]. Especially with the development of the "Belt and Road", this trend will become more obvious in the future. However, along with the increase in 
international nuclear power cooperative items, newer and higher requirements have been implemented for nuclear power project management and equipment design and manufacturing. The development of the international business of nuclear power enterprises has also driven a large number of purchases of nuclear power equipment. As an important part of nuclear power engineering, nuclear power equipment not only guarantees the operation safety of the nuclear power plant, but also is a key factor affecting the progress of the project [4]. In addition, the purchase cost of nuclear power equipment often accounts for more than half of the investment cost of nuclear power engineering construction. Therefore, it is necessary to develop an appropriate and symmetric supplier selection plan for the nuclear power industry to select qualified nuclear power equipment suppliers and improve competitiveness.

This work aims to construct an integrated Analytic Network Process (ANP)-Tomada de Decisão Iterativa Multicritério (TODIM) method to determine the best supplier for international nuclear power projects. Its main contributions can be summarized as follows: Firstly, there are few studies addressed selecting suppliers in the nuclear power industry under the Z-information environment. Therefore, this is the first work to introduce Z-numbers in the selection of nuclear power equipment suppliers, which can effectively deal with the uncertainty of expert preference. Secondly, in view of the influence of the criterion symmetrical interdependence on its weight, ANP and Z-numbers are integrated (i.e., Z-ANP) to determine the weights of the criteria. Thirdly, the TODIM is also improved by Z-numbers, namely Z-TODIM. It is utilized to aggregate all the entire criteria to determine the final ranking, which can comprehensively consider the risk preference and psychological state of decision-makers [5]. Since this work contains many acronyms, a list of acronyms is provided in Table A1 (see Appendix A) to improve readability.

The rest of this paper is structured as follows. Section 2 reviews some studies associated with nuclear power equipment supplier selection. Section 3 introduces some basic theories of Z-numbers. Section 4 proposes a framework for nuclear power equipment supplier selection. Section 5 provides a case study of the Karachi 2-3 international nuclear power project in Pakistan and conducts sensitivity and comparison analyses concerning the final ranking results. Finally, Section 6 draws conclusions.

\section{Literature Review}

\subsection{Supplier Selection Methods}

Supplier selection is one of the most important decisions in Supply Chain Management (SCM), and the performance of the supplier directly affects the whole chain [6]; this issue has also attracted the attention of scholars for a long time. Throughout the literature, the choice of supplier depends on many factors, including cost, technology, quality assurance, etc. Therefore, it is usually considered as a multi-criteria decision-making (MCDM) problem, and some symmetrical methods have been provided to determine the best supplier from a group of alternatives [7]. For instance, Li and Wang [8] applied the extended Qualitative Flexible Multiple (QUALIFLEX) method to solve the problem of green supplier selection in the context of the probability hesitant fuzzy environment. Chen et al. [9] solved the selection problem of low-carbon suppliers by using a novel Archimedean copulas and co-copulas technique. On the basis of social and environmental perspectives, Kannan et al. [10] combined the fuzzy best-worst method (BWM) and the interval VIsekriterijumskao ptimizacija i KOm-promisno Resenje (VIKOR) technique to prioritize sustainable suppliers in circular supply chains.

In previous studies, most symmetrical methods of selecting suppliers were evaluated by crisp or fuzzy numbers. These innovative studies have expanded theoretical foundations, techniques, and practical tools for supplier selection. However, decision-makers often fail to give accurate and reliable evaluation information because of time pressure and humans' limited information processing capabilities [11,12]. Therefore, some scholars have attempted to introduce uncertainty theories to handle imprecision in many MCDM processes [13-15]. Especially, fuzzy logic and its improvements are the most preferred [16]. For instance, Kacprzyk et al. [17] showed how fuzzy logic can be employed to represent a fuzzy majority, which is in many cases closer to the real human perception of the very 
essence of the majority. Bates et al. [18] applied fuzzy logic to medical decision-making in intensive care units. However, classic uncertainty theories ignore the reliability of evaluation information, which may lead to unreasonable final ranking results. In addition, some studies have shown that information from multiple complex sources may be confusing and unreliable [19,20]. In order to address this problem, Zadeh [21] proposed the Z-number to describe the reliability of information, and it can better capture the expression nature of experts. Owing to its superiority and availability, the Z-number has been widely used in logistics service provider selection [22], economy development program selection [23], hospital performance management [24], and so on, but its application in supplier selection is not common yet. In this work, the Z-number is introduced to handle the uncertainty of decision-making, in order to determine the optimal nuclear power equipment supplier.

In 1996, Saaty [25] first proposed the ANP method based on the Analytic Hierarchy Process (AHP), which is particularly suitable for evaluation and decision-making in complex circumstances. In contrast to many other weighting methods (eg., AHP/BWM), the ANP considered the interdependence among criteria very well. It can effectively improve the rationality and scientificity of the criterion weight distribution by constructing a super-matrix [26,27]. Kiani [28] analyzed the critical success factors of sustainable project management in construction by integrating fuzzy Decision-Making and Evaluation Laboratory (DEMATEL) with the ANP. Tian et al. [29] developed an improved ANP-TODIM approach to resolve MCDM problems where the criterion weights are fully unknown, and it has been successfully applied in optimal tourism attraction recommendation. Mistarihi [30] established a decision-support framework for wheelchair design, in which the fuzzy-ANP approach is applied to determine the importance of engineering characteristics. Although the classic or improved ANP method has been applied in many fields and gained high recognition, few studies have captured both the symmetrical interdependence between criteria and the reliability of evaluation information simultaneously. Therefore, the combination of Z-numbers and ANP is meaningful and creative for the selection of nuclear power equipment suppliers.

The basic concept of TODIM was originally proposed by Gomes et al. [31] in 2009. Given the influence of the cognitive level and the emotional and psychological state, TODIM assumes that decision-makers usually have limited rational rather than absolutely rational states $[5,32,33]$. It reflects the behavioral characteristic of experts and has been successfully used in failure risk assessment, location selection, and portfolio allocation [34,35]. In addition, considering that the original TODIM is not suitable for uncertain environments, some researchers have improved it to comply with their research questions. For instance, Krohling and Souza [36] first combined TODIM with fuzzy numbers to solve uncertain decision-making problems. Subsequently, in order to further cope with the uncertainty in the MCDM process, Krohling et al. [37] extended the fuzzy TODIM with Z-numbers, namely Z-TODIM. As a direct extension of classic TODIM, they can effectively handle the fuzziness of decision-making. However, an advantage of Z-TODIM is that it can deeply measure the reliability of evaluation information. In the process of selecting nuclear power equipment suppliers, the psychological state of experts and the reliability of information cannot be ignored, and thus Z-TODIM is used to rank the alternative suppliers in this work.

\subsection{Evaluation Criteria for Nuclear Power Equipment Supplier Selection}

Nuclear power equipment supplier selection can be viewed as choosing the optimal alternative based on a set of technical and economic indicators. However, very few scholars paid attention to the selection of nuclear power equipment suppliers, except for Yang and Wu et al. [38,39]. In a recent study, researchers focused on supplier selection in the agricultural industry [40], construction industry [41], and manufacturing industry [42]. Nevertheless, with the restarting of global nuclear power, the equipment suppliers of nuclear power projects have shown a large-scale growth trend every year. Some of them still have a lot of deficiencies in product design and manufacturing; project quality management systems and nuclear safety awareness need to be further strengthened. Therefore, 
the development of a comprehensive, scientific, and symmetrical nuclear power equipment supplier evaluation index system has become increasingly necessary.

In the few studies available, Yang et al. [38] established a supplier evaluation system on the ground of Daya Bay NPP, including the capability of the completing system, technology, and quality certification system; the capability of the enterprise organization and management; and the performance history. Based on the former, Wu et al. [39] pointed out that cost, service, reliability and credit should also be taken into consideration comprehensively when selecting an optimal nuclear power equipment supplier. The above literature analysis indicates that some reference criteria have been provided to construct an indicator framework. However, the new era has put forward some new standards and requirements for nuclear power equipment suppliers, such as environmental consciousness and the informatization level of the enterprise. Therefore, we consulted some experts from the nuclear power industry, the machinery industry, and economic sectors to identify the appropriate criteria as follows:

(1) Quality assurance $\left(C_{1}\right)$. The NPP usually consists of four parts: nuclear island, convention island, balance of plant, and nuclear fuel assembly $[38,43]$. All the nuclear power equipment of them must strictly comply with the quality standard set by IAEA, and their failure rate should be controlled at a very low level. Once a quality safety accident occurs, suppliers should have good after-sales service capabilities and provide corrective measures in the first place.

(2) Cost control $\left(C_{2}\right)$. In previous studies [44], cost was often regarded as a key factor in supplier selection. Market surveys show that when the quality level of products or services provided by suppliers is the same, nuclear power enterprises tend to choose suppliers with lower prices so as to save the construction and operation costs of NPPs.

(3) Technical capacity $\left(\mathrm{C}_{3}\right)$. The nuclear power industry is a high-tech industry, and the technological level embodies the comprehensive competitiveness of nuclear power enterprises. In general, technical capacity is positively related to quality assurance capacity, but shows a negative correlation with the cost of production [39].

(4) Enterprise qualification $\left(C_{4}\right)$. The qualification of an enterprise is closely related to its financial status, market condition, and industry influence [39,40,45]. In reality, buyers always look to strengthening cooperation with suppliers with a higher credit reputation and industry ranking. Hence, it is necessary to consider the qualification of candidates in the supplier selection process.

(5) Deliver capability $\left(C_{5}\right)$. The delivery cycle and delivery performance are the major concerns in supplier selection $[9,46]$. Specifically, any delay in delivery will result in cost overruns, or even project failure. In addition, whether it can be successfully delivered in a state of emergency should also be considered in the selection of a nuclear power equipment supplier.

(6) Environmental consciousness $\left(\mathrm{C}_{6}\right)$. In recent years, the environmental awareness of the company and the government has gradually increased, and many nuclear power equipment suppliers increasingly focus on efficiency, energy saving, environmental protection equipment, and Research and Development (R \& D). It has also become an important indicator to measure the corporate social responsibility of suppliers [7,41,47].

On the basis of the above analysis, Table 1 describes the details of the nuclear power equipment supplier selection indicator framework. B and C represent the benefit-type criteria and cost-type criteria, respectively.

Table 1. Nuclear power equipment supplier selection criteria.

\begin{tabular}{cccc}
\hline Criteria & Sub-Criteria & Category & Related Literature \\
\hline \multirow{4}{*}{ Quality assurance } & Quality management capacity $C_{11}$ & B & \\
& Quality certification level $C_{12}$ & B & {$[38,43]$} \\
& Acceptance rate $C_{13}$ & B & \\
& Feedback and improvement $C_{14}$ & B & \\
\hline \multirow{2}{*}{ Cost control } & Product price $C_{21}$ & C & \\
& Quantity discount $C_{22}$ & B & {$[44,48]$} \\
& Transportation and installation $\operatorname{cost} C_{23}$ & C & \\
\hline
\end{tabular}


Table 1. Cont.

\begin{tabular}{|c|c|c|c|}
\hline Criteria & Sub-Criteria & Category & Related Literature \\
\hline \multirow{3}{*}{ Technical capacity } & Technical advancement $C_{31}$ & B & \multirow{3}{*}[4,39,49]{} \\
\hline & R\&D capability $C_{32}$ & B & \\
\hline & Technical equipment level $C_{33}$ & B & \\
\hline \multirow{3}{*}{ Enterprise qualification } & Business credit status $C_{41}$ & B & \multirow{3}{*}[39,40]{} \\
\hline & Market reputation $C_{42}$ & B & \\
\hline & Industry ranking $\mathrm{C}_{43}$ & B & \\
\hline \multirow{3}{*}{ Deliver capability } & Delivery cycle $C_{51}$ & C & \multirow{3}{*}[9,46]{} \\
\hline & Rate of delivery in time $C_{52}$ & B & \\
\hline & Emergency delivery capability $C_{53}$ & B & \\
\hline \multirow{2}{*}{$\begin{array}{l}\text { Environmental } \\
\text { consciousness }\end{array}$} & Energy utilization ratio $\mathrm{C}_{61}$ & B & \multirow{2}{*}[7,41,50]{} \\
\hline & Energy-saving measures $C_{62}$ & B & \\
\hline
\end{tabular}

\section{Preliminaries}

Definition 1 ([51]). Let $\widetilde{A}=\left\{\left(x, \mu_{\widetilde{A}}(x)\right) \mid x \in X\right\}$ be a fuzzy set on space X. The membership function of a Triangular Fuzzy Number (TFN) $\widetilde{A}=\left(a_{1}, a_{2}, a_{3}\right)$ is defined as Equation (1). The distance between the two TFNs $\widetilde{A^{\prime}}=\left(a_{1}{ }^{\prime}, a_{2}{ }^{\prime}, a_{3}{ }^{\prime}\right)$ and $\widetilde{A^{\prime \prime}}=\left(a_{1}{ }^{\prime \prime}, a_{2}{ }^{\prime \prime}, a_{3}{ }^{\prime \prime}\right)$ can be calculated as Equation (2).

$$
\begin{gathered}
f_{\widetilde{A}}(x)=\left\{\begin{array}{cc}
\frac{x-a_{1}}{a_{2}-a_{1}}, & a_{1} \leq x<a_{2} \\
\frac{a_{3}-x}{a_{3}-a_{2}}, & a_{2} \leq x<a_{3} \\
0, & \text { otherwise }
\end{array}\right. \\
d\left(\widetilde{A^{\prime}}, \widetilde{A^{\prime \prime}}\right)=\sqrt{\frac{1}{3}\left[\left(a_{1}{ }^{\prime}-a_{1}{ }^{\prime \prime}\right)^{2}+\left(a_{2}{ }^{\prime}-a_{2}{ }^{\prime \prime}\right)^{2}+\left(a_{3^{\prime}}-a_{3^{\prime \prime}}\right)^{2}\right]}
\end{gathered}
$$

where $\mu_{\widetilde{A}}(x): X \rightarrow[0,1]$ is the degree of membership of the element $x$ in $\widetilde{A}$.

Definition 2 ([51]). Assume that $\widetilde{A^{\prime}}=\left(a_{1}{ }^{\prime}, a_{2}{ }^{\prime}, a_{3}{ }^{\prime}\right)$ and $\widetilde{A^{\prime \prime}}=\left(a_{1}{ }^{\prime \prime}, a_{2}{ }^{\prime \prime}, a_{3}{ }^{\prime \prime}\right)$ are TFNs, and the math operations of them are shown below:

$$
\begin{aligned}
& \widetilde{A^{\prime}} \oplus \widetilde{A^{\prime \prime}}=\left(a_{1}{ }^{\prime}+a_{1}{ }^{\prime \prime}, a_{2}{ }^{\prime}+a_{2}{ }^{\prime \prime}, a_{3}{ }^{\prime}+a_{3}{ }^{\prime \prime}\right) \\
& \widetilde{A^{\prime}} \otimes \widetilde{A^{\prime \prime}}=\left(a_{1}{ }^{\prime} a_{1}{ }^{\prime \prime}, a_{2}{ }^{\prime} a_{2}{ }^{\prime \prime}, a_{3}{ }^{\prime} a_{3}{ }^{\prime \prime}\right) \\
& \widetilde{A^{\prime}} \oslash \widetilde{A^{\prime \prime}}=\left(a_{1}^{\prime} / a_{3}{ }^{\prime \prime}, a_{2}{ }^{\prime} / a_{2}{ }^{\prime \prime}, a_{3}{ }^{\prime} / a_{1}{ }^{\prime \prime}\right) \\
& \lambda \widetilde{A^{\prime}}=\lambda\left(a_{1}{ }^{\prime}, a_{2}{ }^{\prime}, a_{3}{ }^{\prime}\right)=\left(\lambda a_{1}{ }^{\prime}, \lambda a_{2}{ }^{\prime}, \lambda a_{3}{ }^{\prime}\right), \lambda \geq 0
\end{aligned}
$$

Definition 3 ([21,52]). A Z-number $Z=(A, B)$ is an ordered pair of regular fuzzy numbers. $A$ is a restriction on the values, which indicates that the uncertain variable is allowed to take. $B$ is a measure of the reliability of $A$. Let $\widetilde{Z}=(\widetilde{A}, \widetilde{B})$ be a Z-number; the component $\widetilde{B}$ can be converted into a crisp number $\alpha$, as in Equation (4). Then, $\widetilde{Z}=(\widetilde{A}, \widetilde{B})$ can be translated into a regular fuzzy number, as in Equation (5).

$$
\begin{gathered}
\alpha=\frac{\int x \mu_{\widetilde{B}}(x) d x}{\int \mu_{\widetilde{B}}(x) d x} \\
\widetilde{Z}^{\prime}=\left\{\mu_{\widetilde{A}^{\prime}}(x)=\sqrt{\alpha} \mu_{\widetilde{A}}(x), x \in[0,1]\right\}
\end{gathered}
$$

where $\widetilde{A}=\left\{\left(x, \mu_{\widetilde{A}}(x)\right) \mid x \in X\right\}$ and $\widetilde{B}=\left\{\left(x, \mu_{\widetilde{B}}(x)\right) \mid x \in X\right\}$ are TFNs.

Definition 4 ([1,53]). In reality, linguistic variables are more convenient for decision-makers [54]. Typically, a Z-number can be expressed in natural language, such as (good, high) and (fairly, very high). Thus, the linguistic terms and corresponding fuzzy numbers are defined in Tables 2 and 3. 
Table 2. Linguistic terms for importance and reliability.

\begin{tabular}{ccc}
\hline Linguistic Term & Triangular Fuzzy Scale & Triangular Fuzzy Reciprocal Scale \\
\hline Just equal & $(1,1,1)$ & $(1,1,1)$ \\
Equal importance (EI) & $(1 / 2,1,3 / 2)$ & $(2 / 3,1,2)$ \\
Weakly importance (WI) & $(1,3 / 2,2)$ & $(1 / 2,2 / 3,1)$ \\
Moderate importance (MI) & $(3 / 2,2,5 / 2)$ & $(2 / 5,1 / 2,2 / 3)$ \\
Very importance (VI) & $(2,5 / 2,3)$ & $(1 / 3,2 / 5,1 / 2)$ \\
Absolutely importance (AI) & $(5 / 2,3,7 / 2)$ & $(2 / 7,1 / 3,2 / 5)$ \\
\hline
\end{tabular}

Table 3. Linguistic terms for alternative ratings.

\begin{tabular}{cccc}
\hline \multicolumn{2}{c}{ Constraint } & \multicolumn{2}{c}{ Reliability } \\
\hline Linguistic Term & Fuzzy Scale & Linguistic Term & Fuzzy Scale \\
\hline Very poor (VP) & $(0,0,0.25)$ & Very low $(\mathrm{VL})$ & $(0,0,0.3)$ \\
Poor (P) & $(0,0.25,0.5)$ & Low $(\mathrm{L})$ & $(0.1,0.3,0.5)$ \\
Fairly (F) & $(0.25,0.5,0.75)$ & Neutral $(\mathrm{N})$ & $(0.3,0.5,0.7)$ \\
Good (G) & $(0.5,0.75,1.0)$ & High $(\mathrm{H})$ & $(0.5,0.7,0.9)$ \\
Very good (VG) & $(0.75,1.0,1.0)$ & Very high $(\mathrm{VH})$ & $(0.7,1.0,1.0)$ \\
\hline
\end{tabular}

Example 1. Let $Z=(V I, H)$ be a Z-number linguistic variable which can be depicted as $Z=(A, B)=(V I$, $H)=[(2,5 / 2,3),(0.5,0.7,0.9)]$. Based on Definition 3 , the part $B$ can be transformed into a crisp number $\alpha=0.7$ by Equation (4). Then, a regular fuzzy number $Z^{\prime}=(\sqrt{0.7} \times 2, \sqrt{0.7} \times 5 / 2, \sqrt{0.7} \times 3)=(1.67,2.09,2.51)$ is obtained.

\section{Methodology}

Based on the previous analysis and discussion, this research proposes an integrated Z-ANP and Z-TODIM method to select the optimal supplier in the nuclear power industry. The flowchart of the integration approach under Z-information is shown in Figure 1. In Phase I, a network model is established based on the symmetrical interdependence of the criteria, so as to determine the criterion weights with Z-ANP. In Phase II, Z-TODIM is applied to obtain the ranking of alternatives. The specific steps of the two phases are described in detail in the following sections.

\subsection{Phase I Determine Criterion Weights with Z-ANP}

In view of the symmetrical interdependence among the criteria or alternatives, Saaty [25] proposed ANP to determine the criterion weights more reasonably. However, the previous studies mainly carried out ANP in real or fuzzy environments, without considering the reliability of information [53]. In this phase, ANP is integrated with Z-numbers, and this includes the following implementation steps.

Step 1. Construct a network model and identify the interdependence of criteria.

In this step, the symmetrical interdependence of criteria is identified by a network model. First, relevant experts from the nuclear power industry and mechanical industry will be invited to form a decision-making group. Next, based on the indicator framework in Table 1, the interrelations among all the criteria are identified on the basis of expert preference. 


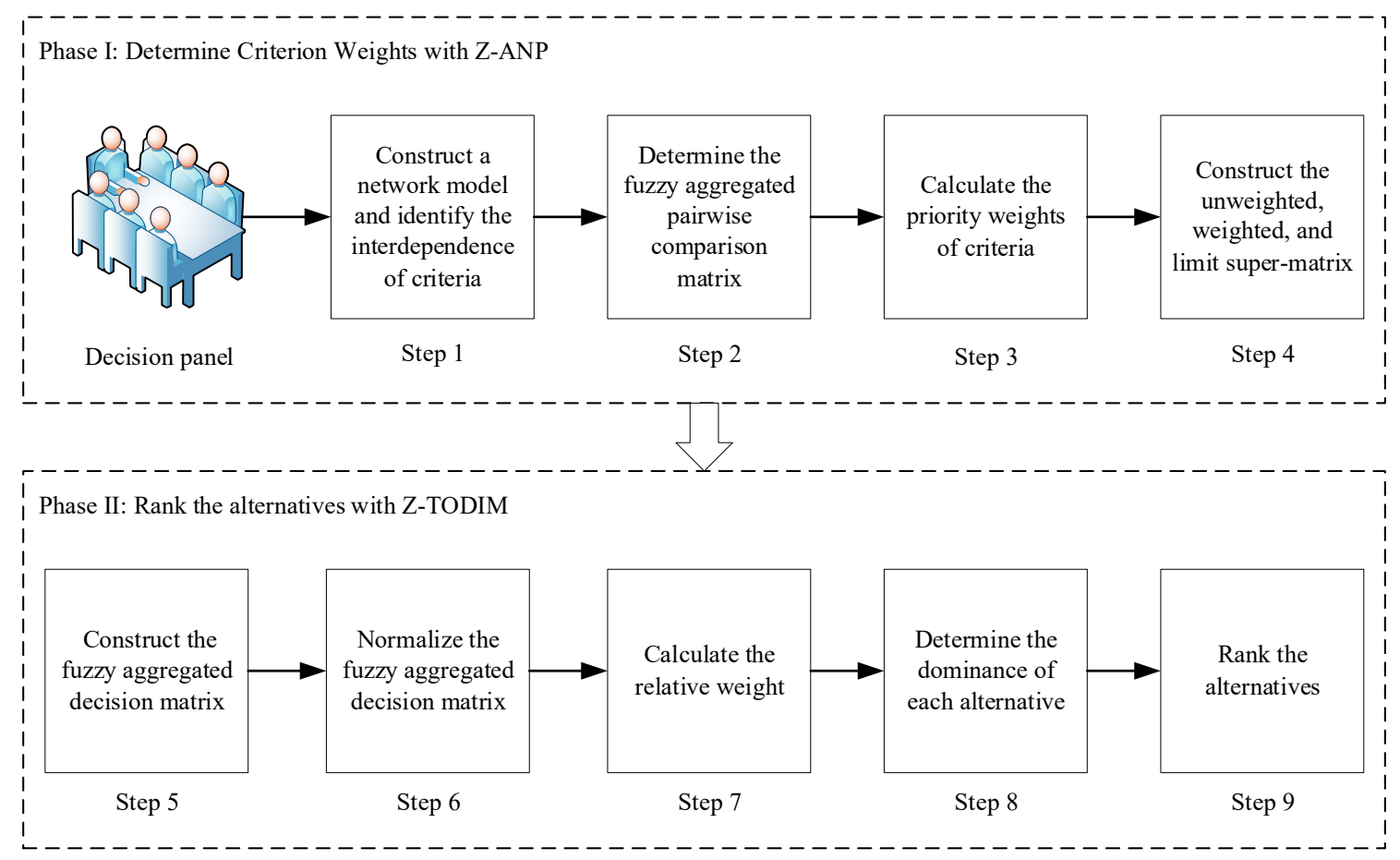

Figure 1. Flowchart of the integrated ANP-TODIM method under Z-information Z-ANP and Z-TODIM method.

Step 2. Determine the fuzzy aggregated pairwise comparison matrix.

Assume that the decision group consists of $K$ experts; since the decision-makers have their own functions in the supplier selection, the same weights are assigned to them. First, the experts give their preferences using Z-number linguistic variables based on the linguistic terms from Tables 2 and 3. Next, the evaluation linguistic terms are translated into triangular fuzzy numbers using Equations (4) and (5). Final, the fuzzy aggregated pairwise comparison matrix is determined by the arithmetic mean, as shown below:

$$
A=\left[a_{i j}\right]_{n \times n}: a_{i j}=\left(m_{i j}, n_{i j}, q_{i j}\right)=\frac{1}{k} \sum_{k=1}^{K}\left[\hat{a}_{i j}\right]_{n \times n}
$$

where $\left[\hat{a}_{i j}\right]_{n \times n}$ is the initial fuzzy pairwise comparison matrices given by experts.

Step 3. Calculate the priority weights of criteria.

Step 3.1. The value of the fuzzy synthetic extent with respect to each element $i(i=1,2, \cdots, n)$ is defined as:

$$
S_{i}=\left(m_{i}, n_{i}, q_{i}\right)=\left(\sum_{j=1}^{n} a_{i j}\right) \otimes\left[\sum_{i=1}^{n} \sum_{j=1}^{n} a_{i j}\right]^{-1}=\left(\frac{\sum_{j=1}^{n} m_{i j}}{\sum_{j=1}^{n} \sum_{j=1}^{n} q_{i j}}, \frac{\sum_{j=1}^{n} n_{i j}}{\sum_{j=1}^{n} \sum_{j=1}^{n} n_{i j}}, \frac{\sum_{j=1}^{n} q_{i j}}{\sum_{j=1}^{n} \sum_{j=1}^{n} m_{i j}}\right)
$$

Step 3.2. The degree of possibility of $S_{i}=\left(m_{i}, n_{i}, q_{i}\right) \geq S_{j}=\left(m_{j}, n_{j}, q_{j}\right)$ is defined as:

$$
V\left(S_{i} \geq S_{j}\right)=\sup \left[\operatorname{Min}\left(\mu_{S_{i}}(x), \mu_{S_{j}}(y)\right)\right]
$$


This can be transformed into:

$$
V\left(S_{i} \geq S_{j}\right)=h g t\left(S_{i} \cap S_{j}\right)=\mu_{S_{i}}(d)=\left\{\begin{array}{cc}
1 & \text { if } n_{i} \geq n_{j} \\
0 & \text { if } m_{j} \geq q_{i} \\
\frac{m_{j}-q_{i}}{\left(n_{i}-q_{i}\right)-\left(n_{j}-m_{j}\right)} & \text { otherwise }
\end{array}\right.
$$

where $d$ is the ordinate of the highest intersection of $\mu_{S_{i}}$ and $\mu_{S_{j}}$, as shown in Figure 2 .

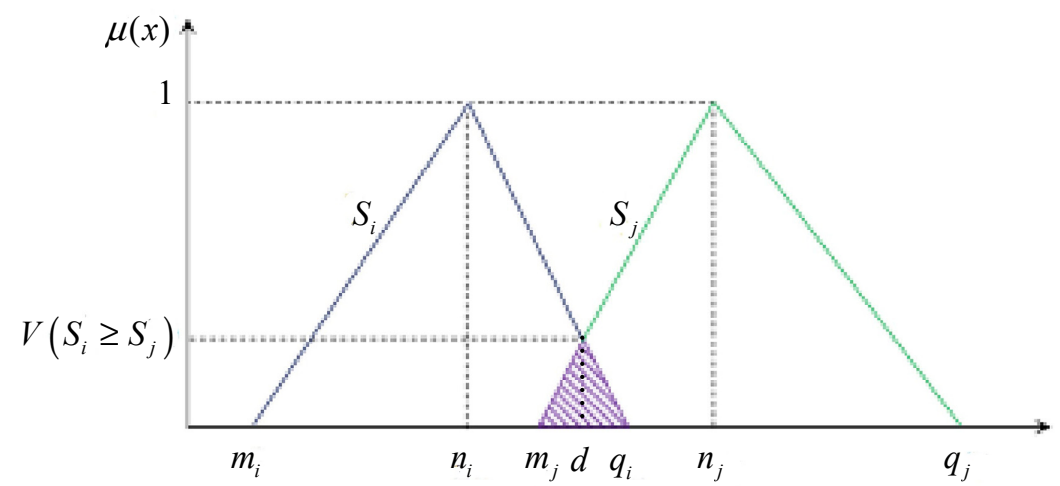

Figure 2. Intersection between $S_{i}$ and $S_{j}$.

Step 3.3. The degree possibility for a convex fuzzy number to be greater than all the other $n-1$ convex fuzzy numbers $S_{j}(j=1,2, \cdots, n, j \neq i)$ can be defined by:

$$
d\left(S_{i}\right)=V\left(S_{i} \geq S_{1}, S_{2}, \cdots, S_{i-1}, S_{i+1}, \cdots, S_{n}\right)=\operatorname{Min}_{j}\left(S_{i} \geq S_{j}\right), \text { for } j=1,2, \cdots, n, j \neq i
$$

Step 3.4. The normalized weight vector $\bar{W}=\left(\bar{w}_{1}, \bar{w}_{2}, \cdots, \bar{w}_{n}\right)^{T}$ is obtained by normalization, as in Equation (11). Then, we construct comparison matrices based on other criteria, so as to obtain the weight matrix $\bar{A}=\left[\bar{W}_{1}, \bar{W}_{2}, \cdots, \bar{W}_{n}\right]$ for the main criteria by repeating the above steps.

$$
\bar{w}_{i}=\frac{d\left(S_{i}\right)}{\sum_{i=1}^{n} d\left(S_{i}\right)}, i=1,2, \cdots, n
$$

Step 4. Construct the unweighted, weighted, and limit super-matrix.

The unweighted super-matrix $W^{\prime}$ is comprised of the importance vectors of the sub-criteria. It is a multi-block matrix where each block describes the relationship between two nodes in a network [28]. Each column in every block is a priority weight vector, which is input into the super-matrix according to the appropriate flow of influence between nodes. Next, the unweighted super-matrix is transformed into the weighted super-matrix $W_{n}=\bar{A} W^{\prime}$. Then, we normalize the weighted super-matrix to obtain $W_{n}{ }^{\prime}$. After that, by taking sequent powers as shown in Equation (12), the normalized weighted super-matrix will converge into a limit super-matrix $\widetilde{W}$. The final weights of criteria $W=\left(w_{1}, \cdots, w_{j}, \cdots, w_{n}\right)$, $1 \leq j \leq n$ can also be obtained from it. The algorithmic principles are given below:

$$
\widetilde{W}=\lim _{t \rightarrow \infty} W_{n}^{\prime 2 t+1}
$$

\subsection{Phase II: Rank the Alternatives with Z-TODIM}

In terms of the ranking of alternative suppliers, an improved TODIM is introduced to deal with this problem in Phase II. The basic theory of TODIM was originally produced by Gomes [31] in 2009, which comprehensively considers the influence of the cognitive level and the emotional and 
psychological state on decision-making. It is further extended by using Z-numbers in this work, and the specific steps are shown as follows.

Step 5. Construct the fuzzy aggregated decision matrix.

This procedure is similar to Step 2, and the final fuzzy aggregated decision matrix is presented as below:

$$
X=\left[x_{i j}\right]_{m \times n}=\left[\begin{array}{cccc}
x_{11} & x_{12} & \cdots & x_{1 n} \\
x_{21} & x_{22} & \cdots & x_{2 n} \\
\vdots & \vdots & \ddots & \vdots \\
x_{m 1} & x_{m 2} & \cdots & x_{m n}
\end{array}\right]
$$

where $\left[x_{i j}\right]_{m \times n}=\frac{1}{k} \sum_{k=1}^{K}\left[\hat{x}_{i j}\right]_{m \times n}$ and $\left[\hat{x}_{i j}\right]_{m \times n}$ are the initial fuzzy decision matrices.

Step 6. Normalize the fuzzy aggregated decision matrix.

The fuzzy aggregated decision matrix $X=\left[x_{i j}\right]_{m \times n}: x_{i j}=\left(\underline{x}_{i j}, x_{i j}, \bar{x}_{i j}\right)$ is transformed into fuzzy normalized decision matrix $R=\left[r_{i j}\right]_{m \times n}: r_{i j}=\left(\underline{r}_{i j}, r_{i j}, \bar{r}_{i j}\right)$, as below:

$$
r_{i j}=\left(\underline{r}_{i j}, r_{i j}, \bar{r}_{i j}\right)=\left\{\begin{array}{l}
\left(\frac{\max _{j}\left(\bar{x}_{i j}\right)-\bar{x}_{i j}}{\max _{j}\left(\bar{x}_{i j}\right)-\min \left(\underline{x}_{i j}\right)}, \frac{\max _{j}\left(\bar{x}_{i j}\right)-x_{i j}}{\max _{j}\left(\bar{x}_{i j}\right)-\min _{j}\left(\underline{x}_{i j}\right)}, \frac{\max _{j}\left(\bar{x}_{i j}\right)-\underline{x}_{i j}}{\max _{j}\left(\bar{x}_{i j}\right)-\min _{j}\left(\underline{x}_{i j}\right)}\right) \text { if } j \in C \\
\left(\frac{\underline{x}_{i j}-\min _{j}\left(\underline{x}_{i j}\right)}{\max _{j}\left(\bar{x}_{i j}\right)-\min _{j}\left(\underline{x}_{i j}\right)}, \frac{x_{i j}-\min _{j}\left(\underline{x}_{i j}\right)}{\max _{j}\left(\bar{x}_{i j}\right)-\min _{j}\left(\underline{x}_{i j}\right)}, \frac{\bar{x}_{i j}-\min _{j}\left(\underline{x}_{i j}\right)}{\max _{j}\left(\bar{x}_{i j}\right)-\min _{j}\left(\underline{x}_{i j}\right)}\right) \text { if } j \in B
\end{array}\right.
$$

where $B$ and $C$ denote the benefit-type and cost-type criteria, as shown in Table 1.

Step 7. Calculate the relative weight.

According to the final weights of criteria $W=\left(w_{1}, \cdots, w_{j}, \cdots, w_{n}\right), 1 \leq j \leq n$ determined from Step 4, the relative weight $w_{j r}$ can be calculated as below:

$$
w_{j r}=\frac{w_{j}}{w_{r}}
$$

where $w_{r}=\max \left\{w_{j} \mid j \in[0, n]\right\}$.

Step 8. Determine the dominance of each alternative.

The dominance of alternative $P_{i}$ over $P_{u}$ can be calculated as below:

$$
\delta\left(P_{i}, P_{u}\right)=\sum_{j=1}^{n} \Phi_{j}\left(P_{i}, P_{u}\right)
$$

where $\Phi_{j}\left(P_{i}, P_{u}\right)$ denotes the contribution of criterion $j$ to function $\delta\left(P_{i}, P_{u}\right)$, and can be determined as below:

$$
\Phi_{j}\left(P_{i}, P_{u}\right)=\left\{\begin{array}{cc}
\sqrt{\frac{w_{j r}}{\sum_{j=1}^{n} w_{j r}} d\left(r_{i j}, r_{u j}\right)} & \text { if }\left(r_{i j}>r_{u j}\right) \\
0 & \text { if }\left(r_{i j}=r_{u j}\right) \\
-\frac{1}{\theta} \sqrt{\frac{\sum_{j=1}^{n} w_{j r}}{w_{j r}} d\left(r_{i j}, r_{u j}\right)} & \text { if }\left(r_{i j}<r_{u j}\right)
\end{array}\right.
$$

where $\theta$ is the recession coefficient, and $d\left(r_{i j}, r_{u j}\right)$ denotes the distance between $r_{i j}$ and $r_{u j}$, which is calculated by Equation (2). 
Step 9. Rank the alternatives.

The ranking of alternatives is obtained in the descending order of global value $\xi_{i}$, which is calculated as below:

$$
\xi_{i}=\frac{\sum_{u=1}^{m} \delta\left(P_{i}, P_{u}\right)-\min \sum_{u=1}^{m} \delta\left(P_{i}, P_{u}\right)}{\max \sum_{u=1}^{m} \delta\left(P_{i}, P_{u}\right)-\min \sum_{u=1}^{m} \delta\left(P_{i}, P_{u}\right)}
$$

\section{Case Study and Result}

Energy shortage is one of the main problems restricting the economic and social development of countries along the Belt and Road. A typical one is Pakistan, which is located in southern Asia, with an area of 880,254 square kilometers, bordering the Arabian Sea. At present, most of Pakistan's electricity is generated from natural gas and oil, which respectively account for $44 \%$ and $29 \%$. However, in recent years, the oil and gas resources in Pakistan have been unable to meet the needs of economic development, and there is a large gap between the supply and demand of primary energy. Therefore, sustainable energy (such as nuclear power and wind power) has attracted the government's attention. The construction of the Karachi 2-3 reactor began in 2015, with a capacity of 2340 MWe. In the choice of its nuclear-grade cable, five suppliers (labeled as $P_{1}-P_{5}$ ) participated in the final bid. The case study is performed to determine the optimal nuclear-grade cable supplier for the Karachi nuclear power project, and the specific procedures are as follows.

\subsection{Phase I: Determine Criterion Weights with Z-ANP}

Step 1. Construct a network model and identify the interdependence of the criteria.

Four professionals $\operatorname{DM}_{k}(k=1,2,3,4)$ engaged in the nuclear power industry, mechanical industry, and economic arena are invited to form a decision group. Based on Table 1, expert consensus formed the proposed network structure of the main criteria, as shown as Figure 3. The symmetrical interdependencies of the sub-criteria are presented in Table A2 (see Appendix B), where " $\sqrt{ }$ " means that the sub-criteria in the row have an influence on the sub-criteria in the column.

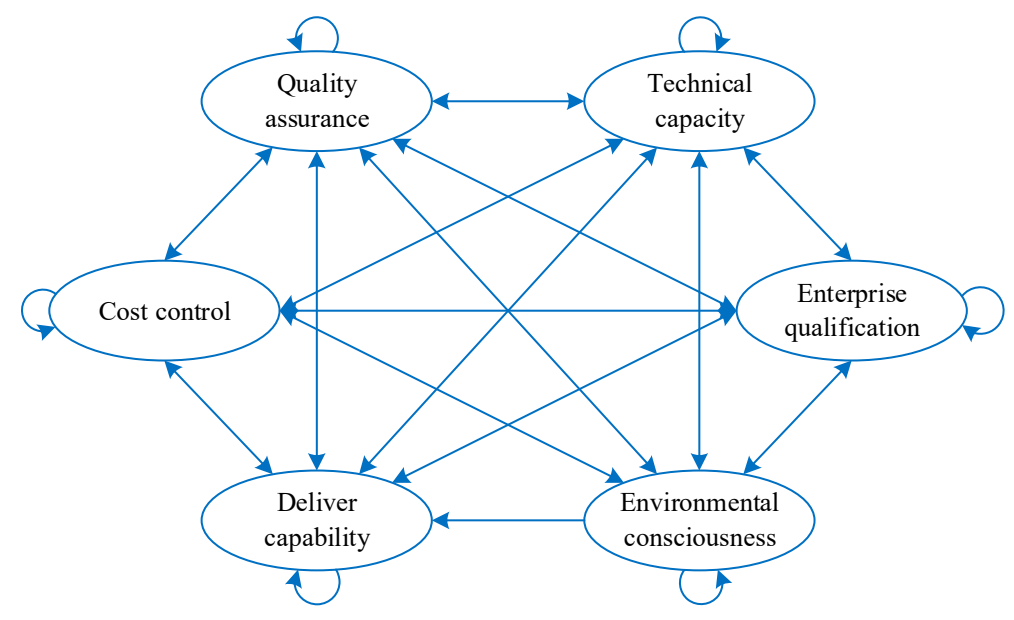

Figure 3. The proposed network structure of the main criteria.

Step 2. Determine the fuzzy aggregated pairwise comparison matrix.

On the basis of Tables 2 and 3, experts use the Z-number linguistic variables for pairwise comparison, and the original evaluation information of the main criteria is shown in Table A3 (see Appendix B). As mentioned in Example 2, the linguistic preference information from all the decision-makers is converted into TFNs. Then, the fuzzy aggregated pairwise comparison matrix is calculated by Equation (6), as presented in Table 4. 
Table 4. Fuzzy aggregated pairwise comparison matrix.

\begin{tabular}{ccccccc}
\hline & $\mathrm{C}_{\mathbf{1}}$ & $\mathrm{C}_{\mathbf{2}}$ & $\mathrm{C}_{\mathbf{3}}$ & $\mathrm{C}_{\mathbf{4}}$ & $\mathrm{C}_{\mathbf{5}}$ & $\mathrm{C}_{\mathbf{6}}$ \\
\hline $\mathrm{C}_{1}$ & $(1.00,1.00,1.00)$ & $(0.55,0.86,1.20)$ & $(0.60,1.00,1.40)$ & $(0.97,1.35,1.74)$ & $(0.81,1.20,1.61)$ & $(0.99,1.39,1.79)$ \\
$\mathrm{C}_{2}$ & $(0.51,0.74,1.24)$ & $(1.00,1.00,1.00)$ & $(0.64,0.93,1.24)$ & $(0.89,1.29,1.69)$ & $(0.73,1.14,1.56)$ & $(1.05,1.44,1.83)$ \\
$\mathrm{C}_{3}$ & $(0.47,0.68,1.22)$ & $(0.55,0.73,1.01)$ & $(1.00,1.00,1.00)$ & $(0.99,1.39,1.79)$ & $(0.80,1.20,1.60)$ & $(1.05,1.48,1.92)$ \\
$\mathrm{C}_{4}$ & $(0.35,0.45,0.65)$ & $(0.38,0.50,0.74)$ & $(0.36,0.47,0.67)$ & $(1.00,1.00,1.00)$ & $(0.38,0.50,0.74)$ & $(0.60,1.00,1.40)$ \\
$\mathrm{C}_{5}$ & $(0.40,0.54,0.81)$ & $(0.45,0.63,1.04)$ & $(0.40,0.53,0.80)$ & $(0.91,1.31,1.71)$ & $(1.00,1.00,1.00)$ & $(0.95,1.33,1.71)$ \\
$\mathrm{C}_{6}$ & $(0.36,0.47,0.67)$ & $(0.33,0.42,0.59)$ & $(0.39,0.51,0.73)$ & $(0.47,0.68,1.22)$ & $(0.35,0.45,0.65)$ & $(1.00,1.00,1.00)$ \\
\hline
\end{tabular}

Step 3. Calculate the priority weights of the criteria.

Based on Table 4, the values of the fuzzy synthetic extent are determined using Equation (7). Subsequently, the degree of possibility of $S_{i} \geq S_{j}$ is calculated from Equations (8) and (9), as presented in Table 5. Then, the no-normalized weights of the main criteria are determined as $d\left(S_{1}\right)=1.000$, $d\left(S_{2}\right)=0.967, d\left(S_{3}\right)=0.992, d\left(S_{4}\right)=0.550, d\left(S_{5}\right)=0.794$, and $d\left(S_{6}\right)=0.451$. Finally, the priority weights of the six main criteria are obtained as $\bar{W}=(0.210,0.203,0.209,0.116,0.167,0.095)^{T}$ by Equation (11). In the same way, the weight vectors of the other main criteria can be calculated to determine the weighted matrix $\bar{A}$.

Table 5. The degree of possibility of $S_{i} \geq S_{j}$.

\begin{tabular}{lllll}
\hline$V\left(S_{1} \geq S_{2}\right)=1.000$ & $V\left(S_{1} \geq S_{3}\right)=1.000$ & $V\left(S_{1} \geq S_{4}\right)=1.000$ & $V\left(S_{1} \geq S_{5}\right)=1.000$ & $V\left(S_{1} \geq S_{6}\right)=1.000$ \\
\hline$V\left(S_{2} \geq S_{1}\right)=0.967$ & $V\left(S_{2} \geq S_{3}\right)=1.000$ & $V\left(S_{2} \geq S_{4}\right)=1.000$ & $V\left(S_{2} \geq S_{5}\right)=1.000$ & $V\left(S_{2} \geq S_{6}\right)=1.000$ \\
$V\left(S_{3} \geq S_{1}\right)=0.959$ & $V\left(S_{3} \geq S_{2}\right)=0.992$ & $V\left(S_{3} \geq S_{4}\right)=1.000$ & $V\left(S_{3} \geq S_{5}\right)=1.000$ & $V\left(S_{3} \geq S_{6}\right)=1.000$ \\
$V\left(S_{4} \geq S_{1}\right)=0.522$ & $V\left(S_{4} \geq S_{2}\right)=0.550$ & $V\left(S_{4} \geq S_{3}\right)=0.554$ & $V\left(S_{4} \geq S_{5}\right)=0.723$ & $V\left(S_{4} \geq S_{6}\right)=1.000$ \\
$V\left(S_{5} \geq S_{1}\right)=0.794$ & $V\left(S_{5} \geq S_{2}\right)=0.825$ & $V\left(S_{5} \geq S_{3}\right)=0.833$ & $V\left(S_{5} \geq S_{4}\right)=1.000$ & $V\left(S_{5} \geq S_{6}\right)=1.000$ \\
$V\left(S_{6} \geq S_{1}\right)=0.451$ & $V\left(S_{6} \geq S_{2}\right)=0.478$ & $V\left(S_{6} \geq S_{3}\right)=0.480$ & $V\left(S_{6} \geq S_{4}\right)=0.913$ & $V\left(S_{6} \geq S_{5}\right)=0.643$ \\
\hline
\end{tabular}

$$
\begin{aligned}
& S_{1}=(4.91,6.80,8.73) \times(26.64,32.57,42.94)^{-1}=(0.114,0.209,0.354), \\
& S_{2}=(4.81,6.53,8.55) \times(26.64,32.57,42.94)^{-1}=(0.112,0.201,0.347), \\
& S_{3}=(4.87,6.47,8.54) \times(26.64,32.57,42.94)^{-1}=(0.113,0.199,0.346), \\
& S_{4}=(3.06,3.92,5.19) \times(26.64,32.57,42.94)^{-1}=(0.071,0.120,0.211), \\
& S_{5}=(4.11,5.33,7.08) \times(26.64,32.57,42.94)^{-1}=(0.096,0.164,0.287), \\
& S_{6}=(2.89,3.52,4.86) \times(26.64,32.57,42.94)^{-1}=(0.067,0.108,0.197) .
\end{aligned}
$$

$$
\bar{A}=\left(\begin{array}{cccccc}
0.210 & 0.314 & 0.263 & 0.279 & 0.204 & 0.266 \\
0.203 & 0.181 & 0.193 & 0.176 & 0.179 & 0.183 \\
0.209 & 0.198 & 0.223 & 0.214 & 0.220 & 0.237 \\
0.116 & 0.104 & 0.131 & 0.124 & 0.111 & 0.162 \\
0.167 & 0.124 & 0.126 & 0.137 & 0.180 & 0 \\
0.095 & 0.079 & 0.064 & 0.070 & 0.106 & 0.152
\end{array}\right)
$$

Step 4. Construct the unweighted, weighted, and limit super-matrix.

The same procedure in the previous step is conducted to determine the symmetrical interdependence of the sub-criteria. Similar to the main criteria, the priority weights of all the sub-criteria can be obtained. On the basis of Algorithm 1, the unweighted super-matrix is constructed as Table A4. By multiplying the weighted matrix of the main criteria with the unweighted super-matrix, the weighted super-matrix is calculated is shown in Table A5. Then, we can determine the limit super-matrix (see Table A6), and the final weights of the eighteen sub-criteria are obtained as shown in Table 6. 


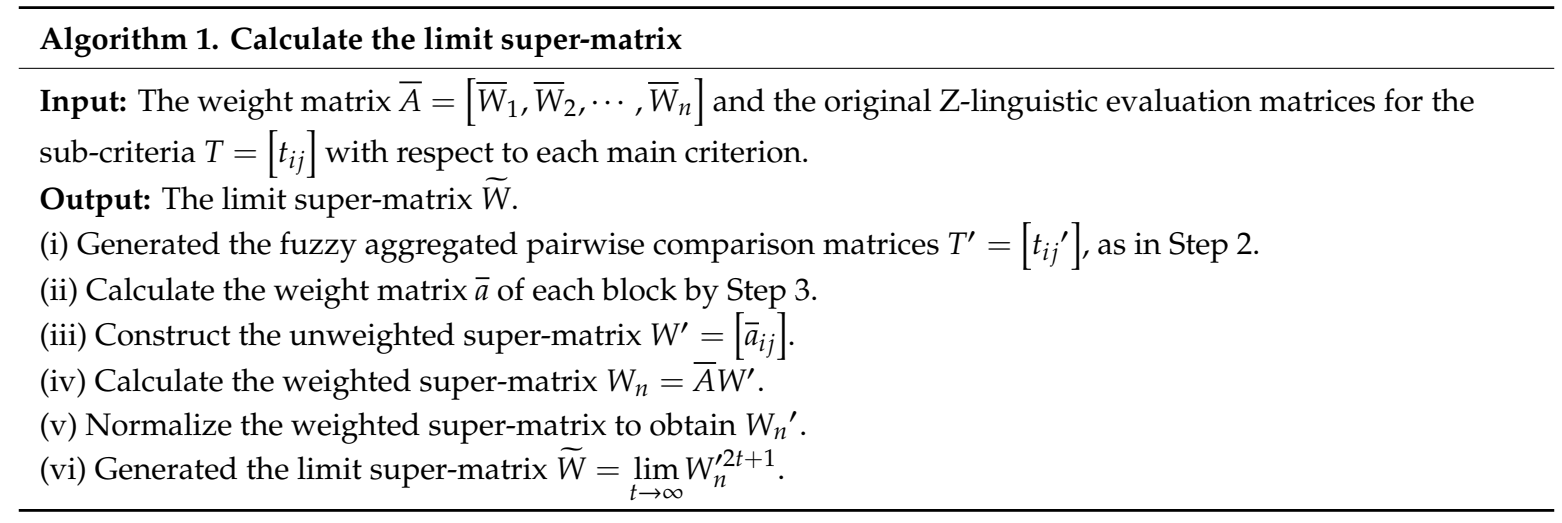

Table 6. Weight distribution of the criteria for nuclear power equipment supplier selection.

\begin{tabular}{ccc}
\hline Criteria & Sub-Criteria & Criteria Weight \\
\hline \multirow{4}{*}{ Quality assurance } & Quality management capacity $C_{11}$ & 0.067 \\
& Quality certification level $C_{12}$ & 0.058 \\
& Acceptance rate $C_{13}$ & 0.062 \\
Cost control & Feedback and improvement $C_{14}$ & 0.052 \\
& Products price $C_{21}$ & 0.083 \\
& Quantity discount $C_{22}$ & 0.037 \\
Technical capacity & Transportation and installation cost $C_{23}$ & 0.066 \\
& Technical advancement $C_{31}$ & 0.089 \\
& R\&D capability $C_{32}$ & 0.068 \\
Enterprise qualification & Technical equipment level $C_{33}$ & 0.071 \\
& Business credit status $C_{41}$ & 0.010 \\
& Market reputation $C_{42}$ & 0.058 \\
& Industry ranking $C_{43}$ & 0.040 \\
\hline \multirow{3}{*}{ Deliver capability } & Delivery cycle $C_{51}$ & 0.052 \\
& Rate of delivery in time $C_{52}$ & 0.046 \\
Environmental & Emergency delivery capability $C_{53}$ & 0.062 \\
\hline consciousness & Energy utilization ratio $C_{61}$ & 0.039 \\
\hline
\end{tabular}

\subsection{Phase II: Rank the Alternatives with Z-TODIM}

Steps 5 and 6. Construct the normalized fuzzy decision matrix.

Experts use the Z-number linguistic variables to determine decision matrices, as presented in Table A7 (see Appendix B), and these can be converted into initial fuzzy decision matrices using Equations (4) and (5). The fuzzy aggregated decision matrix is obtained using Equation (13). Based on Equation (14), the normalized fuzzy decision matrix is determined, as in Table 7. 
Table 7. The normalized fuzzy decision matrix.

\begin{tabular}{cccccc}
\hline & $\mathbf{P}_{\mathbf{1}}$ & $\mathbf{P}_{\mathbf{2}}$ & $\mathbf{P}_{\mathbf{3}}$ & $\mathbf{P}_{\mathbf{4}}$ & $\mathbf{P}_{\mathbf{5}}$ \\
\hline $\mathrm{C}_{11}$ & $(0.036,0.517,1.000)$ & $(0.010,0.474,0.939)$ & $(0.149,0.629,1.000)$ & $(0.068,0.517,0.870)$ & $(0.000,0.464,0.928)$ \\
$\mathrm{C}_{12}$ & $(0.128,0.614,1.000)$ & $(0.028,0.513,1.000)$ & $(0.123,0.558,0.792)$ & $(0.000,0.480,0.865)$ & $(0.000,0.480,0.865)$ \\
$\mathrm{C}_{13}$ & $(0.130,0.610,0.983)$ & $(0.032,0.470,0.810)$ & $(0.027,0.513,1.000)$ & $(0.059,0.513,0.869)$ & $(0.000,0.470,0.940)$ \\
$\mathrm{C}_{14}$ & $(0.000,0.439,0.879)$ & $(0.060,0.529,1.000)$ & $(0.055,0.464,0.767)$ & $(0.140,0.595,0.943)$ & $(0.110,0.504,0.701)$ \\
$\mathrm{C}_{21}$ & $(0.055,0.471,0.887)$ & $(0.174,0.590,1.000)$ & $(0.000,0.432,0.862)$ & $(0.000,0.461,0.917)$ & $(0.110,0.511,0.912)$ \\
$\mathrm{C}_{22}$ & $(0.028,0.513,1.000)$ & $(0.017,0.502,0.988)$ & $(0.000,0.469,0.938)$ & $(0.017,0.502,0.988)$ & $(0.078,0.547,0.915)$ \\
$\mathrm{C}_{23}$ & $(0.114,0.510,0.907)$ & $(0.190,0.600,1.000)$ & $(0.000,0.425,0.850)$ & $(0.053,0.463,0.874)$ & $(0.076,0.487,0.892)$ \\
$\mathrm{C}_{31}$ & $(0.060,0.529,1.000)$ & $(0.039,0.448,0.767)$ & $(0.000,0.438,0.878)$ & $(0.024,0.479,0.933)$ & $(0.145,0.555,0.767)$ \\
$\mathrm{C}_{32}$ & $(0.291,0.661,0.839)$ & $(0.241,0.633,0.839)$ & $(0.277,0.688,0.989)$ & $(0.000,0.419,0.843)$ & $(0.177,0.588,1.000)$ \\
$\mathrm{C}_{33}$ & $(0.109,0.548,0.987)$ & $(0.093,0.532,0.878)$ & $(0.119,0.559,1.000)$ & $(0.000,0.438,0.878)$ & $(0.046,0.454,0.862)$ \\
$\mathrm{C}_{41}$ & $(0.149,0.629,1.000)$ & $(0.026,0.506,0.987)$ & $(0.068,0.517,0.870)$ & $(0.090,0.506,0.731)$ & $(0.000,0.464,0.928)$ \\
$\mathrm{C}_{42}$ & $(0.148,0.660,0.936)$ & $(0.211,0.694,0.936)$ & $(0.010,0.510,0.890)$ & $(0.102,0.602,1.000)$ & $(0.000,0.493,0.872)$ \\
$\mathrm{C}_{43}$ & $(0.131,0.557,0.876)$ & $(0.080,0.491,0.810)$ & $(0.085,0.542,1.000)$ & $(0.000,0.410,0.820)$ & $(0.050,0.491,0.932)$ \\
$\mathrm{C}_{51}$ & $(0.145,0.538,0.931)$ & $(0.000,0.407,0.814)$ & $(0.167,0.561,0.949)$ & $(0.118,0.497,0.877)$ & $(0.167,0.588,1.000)$ \\
$\mathrm{C}_{52}$ & $(0.164,0.594,0.932)$ & $(0.000,0.441,0.886)$ & $(0.200,0.645,1.000)$ & $(0.138,0.553,0.876)$ & $(0.072,0.502,0.932)$ \\
$\mathrm{C}_{53}$ & $(0.183,0.591,1.000)$ & $(0.000,0.413,0.835)$ & $(0.235,0.624,0.835)$ & $(0.005,0.408,0.816)$ & $(0.145,0.539,0.849)$ \\
$\mathrm{C}_{61}$ & $(0.027,0.511,1.000)$ & $(0.000,0.467,0.940)$ & $(0.000,0.473,0.946)$ & $(0.065,0.473,0.685)$ & $(0.201,0.658,1.000)$ \\
$\mathrm{C}_{62}$ & $(0.252,0.617,0.904)$ & $(0.217,0.609,1.000)$ & $(0.183,0.548,0.913)$ & $(0.000,0.357,0.722)$ & $(0.104,0.478,0.857)$ \\
\hline
\end{tabular}

Steps 7 and 8. Calculate the relative weight and determine the overall dominance of each alternative.

Based on Equation (15), the relative weights of the criteria are determined as $W_{j r}=$ $\{0.753,0.652,0.697,0.584,0.933,0.416,0.742,1.000,0.764,0.798,0.112,0.652,0.449,0.584,0.517,0.697,0.438,0.449\}$. According to Equations (16) and (17), the dominance of alternative $P_{i}$ over $P_{u}$ is calculated as below, and the recession coefficient $\theta=1$ in this work.

$$
\delta\left(P_{i}, P_{u}\right)=\left(\begin{array}{ccccc}
0.000 & -4.880 & -7.851 & -0.366 & -5.418 \\
-17.385 & 0.000 & -14.487 & -5.996 & -10.637 \\
-13.152 & -10.382 & 0.000 & -5.087 & -7.659 \\
-24.958 & -17.585 & -19.889 & 0.000 & -14.299 \\
-18.835 & -12.853 & -13.690 & -8.929 & 0.000
\end{array}\right)
$$

Step 9. Rank the alternatives.

Following on Step 8, the global values of alternatives are obtained as $\xi_{1}=1.000, \xi_{2}=0.485$, $\xi_{3}=0.695, \xi_{4}=0.000, \xi_{5}=0.385$. Thus, the final ranking is $P_{1}>P_{3}>P_{2}>P_{5}>P_{4}$, with $P_{1}$ as the best supplier.

\subsection{Results and Discussion}

\subsubsection{Sensitivity Analysis}

The values of $\theta$ reflect the characteristics of experts to avoid risks and losses, and the greater $\theta$ is, the lower loss aversion is. In the research of Kahneman and Tversky [55], the experimental results showed that $\theta$ generally fluctuates between 1 and 2.5. In this part, we modify the recession coefficient to investigate the influence of $\theta$ on the ranking order of alternatives, and the variation results are shown in Table 8 . This indicates that the ranking of alternatives is exactly the same as the proposed ranking. Therefore, the sensitivity analysis reveals that our integrated ZANP-TODIM method can provide reliable results for the selection of nuclear power equipment suppliers. 
Table 8. Ranking of alternatives with different values of $\theta$.

\begin{tabular}{ccccccccc}
\hline \multirow{2}{*}{$\boldsymbol{c}$} & \multicolumn{2}{c}{$\boldsymbol{\theta = 1}$} & \multicolumn{2}{c}{$\boldsymbol{\theta = 1 . 5}$} & \multicolumn{2}{c}{$\boldsymbol{\theta = 2}$} & \multicolumn{2}{c}{$\boldsymbol{\theta = 2 . 5}$} \\
\cline { 2 - 9 } & $\xi$ & Ranking & $\boldsymbol{\xi}$ & Ranking & $\boldsymbol{\xi}$ & Ranking & $\boldsymbol{\xi}$ & Ranking \\
\hline$P_{1}$ & 1.000 & 1 & 1.000 & 1 & 1.000 & 1 & 1.000 & 1 \\
$P_{2}$ & 0.485 & 3 & 0.485 & 3 & 0.485 & 3 & 0.484 & 3 \\
$P_{3}$ & 0.695 & 2 & 0.695 & 2 & 0.696 & 2 & 0.696 & 2 \\
$P_{4}$ & 0.000 & 5 & 0.000 & 5 & 0.000 & 5 & 0.000 & 5 \\
$P_{5}$ & 0.385 & 4 & 0.385 & 4 & 0.385 & 4 & 0.385 & 4 \\
\hline
\end{tabular}

\subsubsection{Comparison Analysis}

In order to verify the applicability and superiority of the proposed method in this work, the fuzzy AHP-Technique for Order Performance by Similarity to Ideal Solution (TOPSIS) approach [56] and rough BWM-Multi-Attribute Ideal Real Comparison Analysis (MAIRCA) [57] technique are compared with our integrated ZANP-TODIM method. In the comparison analysis, the reliability constraint of the evaluation information is excluded from consideration. The linguistic assessment information is directly converted into fuzzy numbers and rough numbers, respectively. Then, the sorting differences between the above MCDM methods are presented in Table 9.

Table 9. Ranking results by different MCDM methods.

\begin{tabular}{cc}
\hline Methods & Ranking Orders \\
\hline Fuzzy AHP-TOPSIS & $P_{1}>P_{5}>P_{3}>P_{2}>P_{4}$ \\
Rough BWM-MAIRCA & $P_{1}>P_{3}>P_{5}>P_{2}>P_{4}$ \\
The proposed ranking & $P_{1}>P_{3}>P_{2}>P_{5}>P_{4}$ \\
\hline
\end{tabular}

As can be seen from Table 9, although the ranking order has changed to some extent, the sorting of $P_{1}$ and $P_{4}$ has remained unchanged. Some minor inconsistencies have occurred between the rankings of $P_{3}, P_{2}$, and $P_{5}$. The reasons can be explained as follows: Firstly, the primary reason for the discrepancies is that the reliability of the assessment information is ignored in the process of comparative experiments. This not only causes information loss, but also increases the uncertainty of the results. Secondly, the TOPSIS, MAIRCA, and TODIM have different ways of normalization, which may also cause fluctuations in the ranking results. In addition, of the three ranking methods, only TODIM considered the risk preference and psychological states of the experts. Finally, the symmetrical interdependence among the criteria is not taken into account in AHP and BWM, and only about half of the evaluation information is effectively used in the BWM method, which results in variations in the criterion weights. Therefore, the proposed integrated ZANP-TODIM approach is more reliable and practical.

\subsubsection{Discussion}

In line with the increasing nuclear power export business, this study proposes an integrated ANP-TODIM method to determine the optimal nuclear power equipment supplier with Z-number information. The ANP method is improved by the Z-number to calculate the criteria weights, which can effectively identify the interrelationships among criteria. The greater the criterion's influence on the other indicators, and the larger the weight. Based on the criterion weights, it is easy to find the key factors affecting the selection of nuclear power equipment suppliers. Referring to Table 6 , the product price $\left(C_{21}\right)$ and technical advancement $\left(C_{31}\right)$ are significantly larger than the others. This indicates that advanced technology and an affordable product price are the prerequisites that affect the competitiveness of nuclear-level suppliers, while the impact of enterprise qualifications is relatively weak. In terms of the ranking of alternatives, the extended Z-TODIM is used to obtain the potential priorities for suppliers, and ultimately determines that $P_{1}$ is the best choice. Referring to Table 8 , the ranking of alternatives has not changed with the variation in parameter $\theta$. This shows that 
our proposed Z-TODIM is less sensitive to the risk preference of decision-makers, and is more reliable and stable than the traditional TODIM method.

In accordance with the analysis and discussion above, it is easy to understand why ANP and TODIM are integrated to construct a nuclear power equipment supplier selection framework. The comparative analysis has also proven the superiority and robustness of the proposed method in this work. However, the computational efficiency of the proposed model needs to be improved in the future. In particular, when the decision information source is complex and there are many candidate suppliers, the computational load of the proposed model is relatively high.

\section{Conclusions, Limitation, and Future Work}

With the intensification of global climate change and the exhaustion of traditional energy sources, nuclear power is increasingly favored by many countries. However, the evaluation and selection of suppliers is always an important issue that has plagued the implementation of nuclear power projects. In this paper, we proposed a MCDM support framework for selecting nuclear power equipment suppliers. Relevant research results can enrich the theoretical foundation and provide references for nuclear power bid evaluation and engineering implementation.

From a methodological viewpoint, compared to other MCDM methods for supplier selection, our research has the following advantages. One the one hand, the Z-number is introduced to express the group decision information, which can well depict the reliability of evaluation information in the decision-making process. On the other hand, the ANP and TODIM methods are extended by Z-numbers, namely Z-ANP and Z-TODIM. Z-ANP is used to determine the importance weight of criteria, and the ranking of alternatives is obtained by Z-TODIM, which effectively combines the advantages of ANP and TODIM. Meanwhile, the symmetrical interdependence of criteria and the risk preferences and psychological states of decision-makers have also been sufficiently considered in our integrated ANP-TODIM method.

From a practical viewpoint, our research effectively identified the key influencing factors on nuclear power equipment supplier selection, which will help decision-makers to select suitable suppliers accurately and flexibly in the process of equipment procurement for overseas nuclear power projects. Simultaneously, faced with the complex background of its global procurement, the proposed support framework is conducive to formulating scientific procurement strategies for nuclear power enterprises, thereby improving the equipment procurement capabilities of purchasers and reducing the possibility of project failure. Furthermore, for those suppliers with poor evaluations, this study provides a reference for improving their performance and competitiveness.

Although this research has made significant contributions to related theories and practices, some limitations remain and need to be considered in future work; at present, we only collect data from several experts, which limits the decision information sources. Meanwhile, the calculation cost of this proposed integrated method is relatively high, and there is a certain amount of information loss in the data conversion process. In the future, we will attempt to invite experts from home and abroad to form a larger group of decision-makers to expand the data sources and application scope of our research. In addition, we would like to conduct a deep research regarding the Z-number arithmetic rules, so as to reduce information loss during data processing and improve the simplicity of the model operation.

Author Contributions: Conceptualization and data curation, T.-L.W.; Methodology, Y.-H.L. and H.-M.P.; Writing-original draft preparation, Y.-H.L. and H.-M.P.; Validation, T.-L.W., H.-M.P., and X.-K.W.; Investigation, X.-K.W.; Project administration, J.-Q.W.; Funding acquisition, J.-Q.W., T.-L.W., and H.-M.P. All authors have read and agreed to the published version of the manuscript.

Funding: This work was supported by the National Natural Science Foundation of China (Nos. 71871128), the Social Science Foundation of Hunan Province of China (Nos. 19JD56), the Research Foundation of Education Bureau of Hunan Province of China (Nos. 19A438), and the Hunan Provincial Innovation Foundation for Postgraduate (Nos. CX20190717).

Acknowledgments: The authors are very grateful to the editor and reviewers for their insightful and constructive comments and suggestions, which were very helpful in improving the quality of the paper. 
Conflicts of Interest: The authors declare no conflict of interest.

\section{Appendix A}

Table A1. List of acronyms.

\begin{tabular}{cc}
\hline Acronym & Definition \\
\hline ANP & Analytic Network Process \\
TODIM & Tomada de Decisão Iterativa Multicritério \\
IAEA & International Atomic Energy Agency \\
NPPs & Nuclear Power Plants \\
SCM & Supply Chain Management \\
MCDM & Multi-criteria Decision-making \\
QUALIFLEX & Qualitative Flexible Multiple Method \\
BWM & Best-worst Method \\
VIKOR & VIsekriterijumskao ptimizacija i KOm-promisno Resenje \\
AHP & Analytic Hierarchy Process \\
DEMATEL & Decision-Making and Evaluation Laboratory \\
R \& D & Research and Development \\
TFN & Triangular Fuzzy Number \\
TOPSIS & Technique for Order Performance by Similarity to Ideal Solution \\
MAIRCA & Multi-attribute Ideal Real Comparison Analysis \\
\hline
\end{tabular}

\section{Appendix B}

Table A2. Mutual influence concerns of sub-criteria.

\begin{tabular}{lllllllllllllllllll}
\hline & $\mathrm{C}_{11}$ & $\mathrm{C}_{12}$ & $\mathrm{C}_{13}$ & $\mathrm{C}_{14}$ & $\mathrm{C}_{21}$ & $\mathrm{C}_{22}$ & $\mathrm{C}_{23}$ & $\mathrm{C}_{31}$ & $\mathrm{C}_{32}$ & $\mathrm{C}_{33}$ & $\mathrm{C}_{41}$ & $\mathrm{C}_{42}$ & $\mathrm{C}_{43}$ & $\mathrm{C}_{51}$ & $\mathrm{C}_{52}$ & $\mathrm{C}_{53}$ & $\mathrm{C}_{61}$ & $\mathrm{C}_{62}$ \\
\hline $\mathrm{C}_{11}$ & & $\sqrt{ }$ & $\sqrt{ }$ & $\sqrt{ }$ & $\sqrt{ }$ & & & & & $\sqrt{ }$ & $\sqrt{ }$ & $\sqrt{ }$ & $\sqrt{ }$ & $\sqrt{ }$ & $\sqrt{ }$ & & \\
$\mathrm{C}_{12}$ & $\sqrt{ }$ & & $\sqrt{ }$ & & $\sqrt{ }$ & & & $\sqrt{ }$ & $\sqrt{ }$ & & & $\sqrt{ }$ & $\sqrt{ }$ & & & & $\sqrt{ }$ & \\
$\mathrm{C}_{13}$ & $\sqrt{ }$ & & & $\sqrt{ }$ & $\sqrt{ }$ & & & $\sqrt{ }$ & $\sqrt{ }$ & $\sqrt{ }$ & & $\sqrt{ }$ & $\sqrt{ }$ & $\sqrt{ }$ & & & $\sqrt{ }$ & $\sqrt{ }$ \\
$C_{14}$ & $\sqrt{ }$ & $\sqrt{ }$ & $\sqrt{ }$ & & $\sqrt{ }$ & & & $\sqrt{ }$ & $\sqrt{ }$ & $\sqrt{ }$ & & $\sqrt{ }$ & & $\sqrt{ }$ & & & & $\sqrt{ }$ \\
$C_{21}$ & & $\sqrt{ }$ & & & & $\sqrt{ }$ & $\sqrt{ }$ & $\sqrt{ }$ & & & $\sqrt{ }$ & & & & & & & $\sqrt{ }$ \\
$C_{22}$ & & & & $\sqrt{ }$ & $\sqrt{ }$ & & $\sqrt{ }$ & & & & & $\sqrt{ }$ & & & & & & \\
$C_{23}$ & & & & $\sqrt{ }$ & $\sqrt{ }$ & $\sqrt{ }$ & & & & & & $\sqrt{ }$ & & $\sqrt{ }$ & $\sqrt{ }$ & $\sqrt{ }$ & & \\
$C_{31}$ & & $\sqrt{ }$ & $\sqrt{ }$ & $\sqrt{ }$ & $\sqrt{ }$ & & & & $\sqrt{ }$ & $\sqrt{ }$ & & $\sqrt{ }$ & $\sqrt{ }$ & & $\sqrt{ }$ & $\sqrt{ }$ & $\sqrt{ }$ & $\sqrt{ }$ \\
$C_{32}$ & $\sqrt{ }$ & $\sqrt{ }$ & & & $\sqrt{ }$ & & & $\sqrt{ }$ & & $\sqrt{ }$ & & $\sqrt{ }$ & $\sqrt{ }$ & & & & $\sqrt{ }$ & $\sqrt{ }$ \\
$C_{33}$ & & $\sqrt{ }$ & $\sqrt{ }$ & $\sqrt{ }$ & $\sqrt{ }$ & & & $\sqrt{ }$ & $\sqrt{ }$ & & $\sqrt{ }$ & $\sqrt{ }$ & $\sqrt{ }$ & $\sqrt{ }$ & $\sqrt{ }$ & $\sqrt{ }$ & $\sqrt{ }$ & \\
$C_{41}$ & $\sqrt{ }$ & & & & & & & & & & & $\sqrt{ }$ & $\sqrt{ }$ & & & & & \\
$C_{42}$ & $\sqrt{ }$ & $\sqrt{ }$ & $\sqrt{ }$ & & $\sqrt{ }$ & & & $\sqrt{ }$ & $\sqrt{ }$ & & $\sqrt{ }$ & & $\sqrt{ }$ & & $\sqrt{ }$ & $\sqrt{ }$ & $\sqrt{ }$ & $\sqrt{ }$ \\
$C_{43}$ & $\sqrt{ }$ & $\sqrt{ }$ & $\sqrt{ }$ & $\sqrt{ }$ & $\sqrt{ }$ & & & $\sqrt{ }$ & & & $\sqrt{ }$ & $\sqrt{ }$ & & & $\sqrt{ }$ & & $\sqrt{ }$ & \\
$C_{51}$ & $\sqrt{ }$ & & & $\sqrt{ }$ & $\sqrt{ }$ & & $\sqrt{ }$ & $\sqrt{ }$ & & $\sqrt{ }$ & & $\sqrt{ }$ & $\sqrt{ }$ & & & $\sqrt{ }$ & & \\
$C_{52}$ & & & $\sqrt{ }$ & $\sqrt{ }$ & $\sqrt{ }$ & & $\sqrt{ }$ & $\sqrt{ }$ & & $\sqrt{ }$ & $\sqrt{ }$ & $\sqrt{ }$ & $\sqrt{ }$ & & & $\sqrt{ }$ & & \\
$C_{53}$ & & & & $\sqrt{ }$ & $\sqrt{ }$ & & $\sqrt{ }$ & $\sqrt{ }$ & $\sqrt{ }$ & $\sqrt{ }$ & $\sqrt{ }$ & $\sqrt{ }$ & $\sqrt{ }$ & $\sqrt{ }$ & $\sqrt{ }$ & & & $\sqrt{ }$ \\
$C_{61}$ & & $\sqrt{ }$ & & $\sqrt{ }$ & $\sqrt{ }$ & & & $\sqrt{ }$ & $\sqrt{ }$ & $\sqrt{ }$ & $\sqrt{ }$ & $\sqrt{ }$ & & $\sqrt{ }$ & & $\sqrt{ }$ & & $\sqrt{ }$ \\
$C_{62}$ & & $\sqrt{ }$ & $\sqrt{ }$ & $\sqrt{ }$ & $\sqrt{ }$ & & & $\sqrt{ }$ & $\sqrt{ }$ & $\sqrt{ }$ & & $\sqrt{ }$ & $\sqrt{ }$ & $\sqrt{ }$ & & & $\sqrt{ }$ \\
\hline
\end{tabular}


Table A3. The original evaluation information of the main criteria using Z-linguistic variables.

\begin{tabular}{|c|c|c|c|c|c|c|c|}
\hline Expert & Criteria & $\mathrm{C}_{1}$ & $\mathrm{C}_{2}$ & $\mathrm{C}_{3}$ & $\overline{C_{4}}$ & $\overline{C_{5}}$ & $\overline{C_{6}}$ \\
\hline \multirow{6}{*}{$\mathrm{DM}_{1}$} & $\mathrm{C}_{1}$ & Just equal & $(\mathrm{MI}, \mathrm{N})$ & $(\mathrm{WI}, \mathrm{H})$ & (MI, H) & $(\mathrm{WI}, \mathrm{H})$ & (MI, H) \\
\hline & $\mathrm{C}_{2}$ & $\left(\mathrm{MI}^{-1}, \mathrm{~N}\right)$ & Just equal & $\left(\mathrm{MI}^{-1}, \mathrm{~N}\right)$ & $(\mathrm{WI}, \mathrm{N})$ & $(\mathrm{EI}, \mathrm{H})$ & $(\mathrm{MI}, \mathrm{N})$ \\
\hline & $\mathrm{C}_{3}$ & $\left(\mathrm{WI}^{-1}, \mathrm{H}\right)$ & $(\mathrm{MI}, \mathrm{N})$ & Just equal & (MI, H) & $(\mathrm{WI}, \mathrm{N})$ & (MI, H) \\
\hline & $\mathrm{C}_{4}$ & $\left(\mathrm{MI}^{-1}, \mathrm{H}\right)$ & $\left(\mathrm{WI}^{-1}, \mathrm{~N}\right)$ & $\left(\mathrm{MI}^{-1}, \mathrm{H}\right)$ & Just equal & $\left(\mathrm{MI}^{-1}, \mathrm{H}\right)$ & (WI, H) \\
\hline & $\mathrm{C}_{5}$ & $\left(\mathrm{WI}^{-1}, \mathrm{H}\right)$ & $\left(\mathrm{EI}^{-1}, \mathrm{H}\right)$ & $\left(\mathrm{WI}^{-1}, \mathrm{~N}\right)$ & $(\mathrm{MI}, \mathrm{H})$ & Just equal & $(\mathrm{MI}, \mathrm{N})$ \\
\hline & $\mathrm{C}_{6}$ & $\left(\mathrm{MI}^{-1}, \mathrm{H}\right)$ & $\left(\mathrm{MI}^{-1}, \mathrm{~N}\right)$ & $\left(\mathrm{MI}^{-1}, \mathrm{H}\right)$ & $\left(\mathrm{WI}^{-1}, \mathrm{H}\right)$ & $\left(\mathrm{MI}^{-1}, \mathrm{~N}\right)$ & Just equal \\
\hline \multirow{6}{*}{$\mathrm{DM}_{2}$} & $\mathrm{C}_{1}$ & Just equal & $(\mathrm{EI}, \mathrm{H})$ & $(\mathrm{EI}, \mathrm{H})$ & $(\mathrm{WI}, \mathrm{N})$ & $(\mathrm{WI}, \mathrm{H})$ & $(\mathrm{WI}, \mathrm{N})$ \\
\hline & $\mathrm{C}_{2}$ & $\left(\mathrm{EI}^{-1}, \mathrm{H}\right)$ & Just equal & $(\mathrm{WI}, \mathrm{N})$ & (WI, VH) & $(\mathrm{WI}, \mathrm{H})$ & $(\mathrm{MI}, \mathrm{N})$ \\
\hline & $\mathrm{C}_{3}$ & $\left(\mathrm{EI}^{-1}, \mathrm{H}\right)$ & $\left(\mathrm{WI}^{-1}, \mathrm{~N}\right)$ & Just equal & $(\mathrm{MI}, \mathrm{N})$ & (WI, VH) & (WI, VH) \\
\hline & $\mathrm{C}_{4}$ & $\left(\mathrm{WI}^{-1}, \mathrm{~N}\right)$ & $\left(\mathrm{WI}^{-1}, \mathrm{VH}\right)$ & $\left(\mathrm{MI}^{-1}, \mathrm{~N}\right)$ & Just equal & $\left(\mathrm{WI}^{-1}, \mathrm{H}\right)$ & $(\mathrm{EI}, \mathrm{H})$ \\
\hline & $\mathrm{C}_{5}$ & $\left(\mathrm{WI}^{-1}, \mathrm{H}\right)$ & $\left(\mathrm{WI}^{-1}, \mathrm{H}\right)$ & $\left(\mathrm{WI}^{-1}, \mathrm{VH}\right)$ & (WI, H) & Just equal & (MI, N) \\
\hline & $\mathrm{C}_{6}$ & $\left(\mathrm{WI}^{-1}, \mathrm{~N}\right)$ & $\left(\mathrm{MI}^{-1}, \mathrm{~N}\right)$ & $\left(\mathrm{WI}^{-1}, \mathrm{VH}\right)$ & $\left(\mathrm{EI}^{-1}, \mathrm{H}\right)$ & $\left(\mathrm{MI}^{-1}, \mathrm{~N}\right)$ & Just equal \\
\hline \multirow{6}{*}{$\mathrm{DM}_{3}$} & $\mathrm{C}_{1}$ & Just equal & $\left(\mathrm{WI}^{-1}, \mathrm{~N}\right)$ & $(\mathrm{EI}, \mathrm{H})$ & $(\mathrm{MI}, \mathrm{N})$ & (WI, H) & $(\mathrm{MI}, \mathrm{N})$ \\
\hline & $\mathrm{C}_{2}$ & $(\mathrm{WI}, \mathrm{N})$ & Just equal & (WI, H) & $(\mathrm{MI}, \mathrm{N})$ & (WI, VH) & (MI, H) \\
\hline & $\mathrm{C}_{3}$ & $\left(\mathrm{EI}^{-1}, \mathrm{H}\right)$ & $\left(\mathrm{WI}^{-1}, \mathrm{H}\right)$ & Just equal & (WI, VH) & $(\mathrm{WI}, \mathrm{N})$ & $(\mathrm{MI}, \mathrm{N})$ \\
\hline & $\mathrm{C}_{4}$ & $\left(\mathrm{MI}^{-1}, \mathrm{~N}\right)$ & $\left(\mathrm{MI}^{-1}, \mathrm{~N}\right)$ & $\left(\mathrm{WI}^{-1}, \mathrm{VH}\right)$ & Just equal & $\left(\mathrm{WI}^{-1}, \mathrm{H}\right)$ & $(\mathrm{WI}, \mathrm{N})$ \\
\hline & $\mathrm{C}_{5}$ & $\left(\mathrm{WI}^{-1}, \mathrm{H}\right)$ & $\left(\mathrm{WI}^{-1}, \mathrm{VH}\right)$ & $\left(\mathrm{WI}^{-1}, \mathrm{~N}\right)$ & $(\mathrm{WI}, \mathrm{H})$ & Just equal & (WI, VH) \\
\hline & $\mathrm{C}_{6}$ & $\left(\mathrm{MI}^{-1}, \mathrm{~N}\right)$ & $\left(\mathrm{MI}^{-1}, \mathrm{H}\right)$ & $\left(\mathrm{MI}^{-1}, \mathrm{~N}\right)$ & $\left(\mathrm{WI}^{-1}, \mathrm{~N}\right)$ & $\left(\mathrm{WI}^{-1}, \mathrm{VH}\right)$ & Just equal \\
\hline \multirow{6}{*}{$\mathrm{DM}_{4}$} & $\mathrm{C}_{1}$ & Just equal & $(\mathrm{EI}, \mathrm{N})$ & $(\mathrm{WI}, \mathrm{N})$ & (WI, H) & $(\mathrm{WI}, \mathrm{N})$ & (WI, VH) \\
\hline & $\mathrm{C}_{2}$ & $\left(\mathrm{EI}^{-1}, \mathrm{~N}\right)$ & Just equal & (WI, N) & (WI, H) & (WI, N) & (WI, H) \\
\hline & $\mathrm{C}_{3}$ & $\left(\mathrm{WI}^{-1}, \mathrm{~N}\right)$ & $\left(\mathrm{WI}^{-1}, \mathrm{~N}\right)$ & Just equal & (WI, N) & (WI, H) & (WI, VH) \\
\hline & $\mathrm{C}_{4}$ & $\left(\mathrm{WI}^{-1}, \mathrm{H}\right)$ & $\left(\mathrm{WI}^{-1}, \mathrm{H}\right)$ & $\left(\mathrm{WI}^{-1}, \mathrm{~N}\right)$ & Just equal & $\left(\mathrm{WI}^{-1}, \mathrm{~N}\right)$ & $(\mathrm{EI}, \mathrm{H})$ \\
\hline & $\mathrm{C}_{5}$ & $\left(\mathrm{WI}^{-1}, \mathrm{~N}\right)$ & $\left(\mathrm{WI}^{-1}, \mathrm{~N}\right)$ & $\left(\mathrm{WI}^{-1}, \mathrm{H}\right)$ & $(\mathrm{WI}, \mathrm{N})$ & Just equal & (WI, N) \\
\hline & $\mathrm{C}_{6}$ & $\left(\mathrm{WI}^{-1}, \mathrm{VH}\right)$ & $\left(\mathrm{WI}^{-1}, \mathrm{H}\right)$ & $\left(\mathrm{WI}^{-1}, \mathrm{VH}\right)$ & $\left(\mathrm{EI}^{-1}, \mathrm{H}\right)$ & $\left(\mathrm{WI}^{-1}, \mathrm{~N}\right)$ & Just equal \\
\hline
\end{tabular}

Table A4. The unweighted super-matrix.

\begin{tabular}{|c|c|c|c|c|c|c|c|c|c|c|c|c|c|c|c|c|c|c|}
\hline & 11 & 12 & 13 & 14 & 21 & 22 & 23 & 31 & $C_{32}$ & 33 & $C_{41}$ & 42 & $\mathrm{C}_{43}$ & 51 & -52 & $\mathrm{C}_{53}$ & $C_{61}$ & $C_{62}$ \\
\hline $\mathrm{C}_{11}$ & 000 & 67 & 375 & 636 & 217 & 000 & 000 & 000 & 00 & 393 & 000 & 324 & 37 & 334 & .000 & .000 & 000 & .000 \\
\hline $\mathrm{C}_{12}$ & 45 & & & & & & & & & & & & & & & & & 000 \\
\hline $\mathrm{C}_{13}$ & 362 & & 000 & 64 & 16 & 00 & & & & & & & & & & & & 435 \\
\hline $\mathrm{C}_{14}$ & 293 & & 0.261 & & 04 & & & & & & & & & & & & & 0.565 \\
\hline $\mathrm{C}_{21}$ & 000 & & & & & & & & & & & & & & & & & .000 \\
\hline $\mathrm{C}_{22}$ & 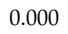 & & & & & & & & & & & & & & & & & \\
\hline $\mathrm{C}_{23}$ & & & & & & & & & & & & & & & & & & \\
\hline$C_{31}$ & & & & & & & & & & & & & & & & & & \\
\hline $\mathrm{C}_{32}$ & 1 & & & & & & & & & & & & & & & & & 180 \\
\hline $\mathrm{C}_{33}$ & & & & & & & & & & & & & & & & & & 000 \\
\hline $\mathrm{C}_{41}$ & & & & & & & & & & & & & & & & & & 000 \\
\hline $\mathrm{C}_{42}$ & & & & & & & & & & & & & & & & & & 000 \\
\hline $\mathrm{C}_{43}$ & & & & & & & & & & & & & & & & & & 00 \\
\hline$C_{51}$ & & & & & & & & & & & & & & & & & & 000 \\
\hline$C_{52}$ & & & & & & & & & & & & & & & & & & \\
\hline $\mathrm{C}_{53}$ & & & & & & & & & & & & & & & & & & .000 \\
\hline $\mathrm{C}_{61}$ & & & & & & & & & & & & & & & & & 000 & .000 \\
\hline$C_{62}$ & 0.000 & 0.445 & 1.000 & 0.487 & 0.499 & 0.000 & 0.000 & 0.436 & 0.379 & 0.468 & 0.000 & 0.578 & 1.000 & 0.500 & 0.000 & 0.000 & 1.000 & 0.000 \\
\hline
\end{tabular}


Table A5. The weighted super-matrix.

\begin{tabular}{|c|c|c|c|c|c|c|c|c|c|c|c|c|c|c|c|c|c|c|}
\hline & 11 & 12 & 13 & 14 & 21 & $C_{22}$ & 23 & -31 & $C_{32}$ & 33 & $\mathrm{C}_{41}$ & 42 & $C_{43}$ & $C_{51}$ & $C_{52}$ & $\mathrm{C}_{53}$ & $C_{61}$ & $C_{62}$ \\
\hline $\mathrm{C}_{11}$ & 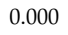 & 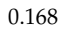 & 年 & & 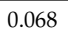 & 0.000 & 0000 & 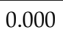 & & & r & No & 0.127 & 等 & 0.228 & 00 & 000 & .000 \\
\hline$C_{12}$ & & & & & & & & & & & & & & & & & 7 & .000 \\
\hline $\mathrm{C}_{13}$ & 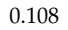 & & & & & & & & & & & & & & & & & 16 \\
\hline $\mathrm{C}_{14}$ & 088 & & & & & & & & & & & & & & & & & 150 \\
\hline $\mathrm{C}_{21}$ & & & & & & & & & & & & & & & & & & 183 \\
\hline $\mathrm{C}_{22}$ & & & & & & & & & & & & & & & & & & 000 \\
\hline $\mathrm{C}_{23}$ & & & & & & & & & & & & & & & & & & 000 \\
\hline $\mathrm{C}_{31}$ & & & & & & & & & & & & & & & & & & 23 \\
\hline & & & & & & & & & & & & & & & & & & 114 \\
\hline & & & & & & & & & & & & & & & & & & 00 \\
\hline & & & 0 & & & & & 0 & & & & & & & & 0.000 & & .000 \\
\hline 2 & 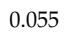 & 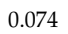 & 73 & & & & & & & 0 & 6 & U & 4 & 0 & & 0.139 & 9 & 0.162 \\
\hline 3 & 05 & 66 & 773 & & & & & $0 \Omega$ & & 0 & 8 & 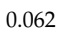 & 0 & 0 & & 0.000 & 69 & 0.000 \\
\hline & 38 & & & & & & & 6 & & 2 & 0 & 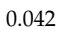 & 8 & 0 & & 0.126 & .000 & 0.000 \\
\hline & 000 & & & & & & & 3 & & & & & & & & 0.101 & & 0.000 \\
\hline & 000 & & & & & & & & & & & & & & & 0.000 & & .000 \\
\hline & 000 & & 10 & & & & & & & & & & & & & 0.133 & & 0.152 \\
\hline $\mathrm{C}_{62}$ & 0.000 & 0.051 & 0.119 & 0.046 & 0.039 & 0.000 & 0.000 & 0.028 & 0.030 & 0.044 & 0.000 & 0.040 & 0.085 & 0.060 & 0.000 & 0.000 & 0.186 & 0.000 \\
\hline
\end{tabular}

Table A6. The limit super-matrix.

\begin{tabular}{|c|c|c|c|c|c|c|c|c|c|c|c|c|c|c|c|c|c|c|}
\hline & $C_{11}$ & $C_{12}$ & $\mathrm{C}_{13}$ & $C_{14}$ & $C_{21}$ & $\mathrm{C}_{22}$ & $\mathrm{C}_{23}$ & $C_{31}$ & $C_{32}$ & $\mathrm{C}_{33}$ & $\mathrm{C}_{41}$ & $\mathrm{C}_{42}$ & $\mathrm{C}_{43}$ & $C_{51}$ & $C_{52}$ & $\mathrm{C}_{53}$ & $\mathrm{C}_{61}$ & $C_{62}$ \\
\hline $\mathrm{C}_{11}$ & 067 & 0.067 & 0.067 & 0.067 & 0.067 & 0.067 & 0.067 & 0.067 & 0.067 & 0.067 & 0.067 & 0.067 & 0.067 & .067 & 0.067 & .067 & 0.067 & .067 \\
\hline $\mathrm{C}_{12}$ & 0.058 & 0.058 & 0.058 & 0.058 & 0.058 & 0.058 & 0.058 & 0.058 & 0.058 & 0.058 & 0.058 & 058 & 0.058 & 058 & 058 & .058 & 058 & 058 \\
\hline $\mathrm{C}_{13}$ & 0.062 & 0.062 & 0.062 & 0.062 & 0.062 & 0.062 & 0.062 & 0.062 & 0.062 & 0.062 & 0.062 & 062 & 0.062 & 062 & 62 & 062 & 62 & .062 \\
\hline $\mathrm{C}_{14}$ & 0.052 & 0.052 & 0.052 & 0.052 & 0.052 & 0.052 & 2 & 0.052 & 0.052 & 0.052 & 0.052 & 52 & 0.052 & 052 & 52 & 052 & 0.052 & 0.052 \\
\hline $\mathrm{C}_{21}$ & 0.083 & 0.083 & 0.083 & 0.083 & 0.083 & 0.083 & 0. & 0.083 & 0.083 & 0.083 & 0.083 & 0.083 & 0.083 & .083 & 0.083 & 0.083 & 0.083 & 0.083 \\
\hline $\mathrm{C}_{22}$ & 0.037 & 0.037 & 0.037 & 0.037 & 0.037 & 0.037 & 0.037 & 0.037 & 0.037 & 0.037 & 0.037 & 0.037 & 0.037 & 0.037 & 0.037 & 0.037 & 0.037 & 0.037 \\
\hline $\mathrm{C}_{23}$ & 0.066 & 0.066 & 0.066 & 0.066 & 0.066 & 0.066 & 0.066 & 0.066 & 0.066 & 0.066 & 0.066 & 0.066 & 0.066 & 0.066 & 0.066 & 0.066 & 0.066 & 0.066 \\
\hline $\mathrm{C}_{31}$ & 0.089 & 0.089 & 0.089 & 0.089 & 0.089 & 0.089 & 0.089 & 0.089 & 0.089 & 0.089 & 0.089 & 0.089 & 0.089 & 0.089 & 0.089 & 0.089 & 0.089 & 0.089 \\
\hline $\mathrm{C}_{32}$ & 0.068 & 0.068 & 0.068 & 0.068 & 0.068 & 0.068 & 0.068 & 0.068 & 0.068 & 0.068 & 0.068 & 0.068 & 0.068 & 0.068 & 0.068 & 0.068 & 0.068 & 0.068 \\
\hline $\mathrm{C}_{33}$ & 0.071 & 0.071 & 0.071 & 0.071 & 0.071 & 0.071 & 0.071 & 0.071 & 0.071 & 0.071 & 0.071 & 0.071 & 0.071 & 0.071 & 0.071 & 0.071 & 0.071 & 0.071 \\
\hline $\mathrm{C}_{41}$ & 0.010 & 0.010 & 0.010 & 0.010 & 0.010 & 0.010 & 0.010 & 0.010 & 0.010 & 0.010 & 0.010 & 0.010 & 0.010 & 0.010 & 0.010 & 0.010 & 0.010 & 0.010 \\
\hline $\mathrm{C}_{42}$ & 0.058 & 0.058 & 0.058 & 0.058 & 0.058 & 0.058 & 0.058 & 0.058 & 0.058 & 0.058 & 0.058 & 0.058 & 0.058 & 0.058 & 0.058 & 0.058 & 0.058 & 0.058 \\
\hline $\mathrm{C}_{43}$ & 0.040 & . 040 & 0.040 & 0.040 & 0.040 & 0.040 & 0.040 & 0.040 & 0.040 & 0.040 & 0.040 & 0.040 & 0.040 & 0.040 & 0.040 & 0.040 & 0.040 & 0.040 \\
\hline$C_{51}$ & 0.052 & 052 & 0.052 & 0.052 & 0.052 & 0.052 & 0.052 & 0.052 & 0.052 & 0.052 & 0.052 & 0.052 & 0.052 & 0.052 & 0.052 & 0.052 & 0.052 & 0.052 \\
\hline$C_{52}$ & 0.046 & 046 & 0.046 & 1.046 & 0.046 & 0.046 & 0.046 & 0.046 & 0.046 & 0.046 & 0.046 & 0.046 & 0.046 & 0.046 & 0.046 & 0.046 & 0.046 & 0.046 \\
\hline $\mathrm{C}_{53}$ & 0.062 & 062 & 0.062 & .062 & 0.062 & .062 & .0 & 0.062 & 0.062 & 0.062 & 0.062 & 0.062 & 0.062 & 0.062 & 0.062 & 0.062 & 0.062 & 0.062 \\
\hline$C_{61}$ & 0.039 & 0.039 & 0.039 & 0.039 & 0.039 & 0.039 & 0.039 & 0.039 & 0.039 & 0.039 & 0.039 & 0.039 & 0.039 & 0.039 & 0.039 & 0.039 & 0.039 & 0.039 \\
\hline $\mathrm{C}_{62}$ & 0.040 & 0.040 & 0.040 & 0.040 & 0.040 & 0.040 & 0.040 & 0.040 & 0.040 & 0.040 & 0.040 & 0.040 & 0.040 & 0.040 & 0.040 & 0.040 & 0.040 & 0.040 \\
\hline
\end{tabular}


Table A7. The original evaluation information for rating alternatives using Z-linguistic variables.

\begin{tabular}{|c|c|c|c|c|c|c|c|c|c|c|c|c|}
\hline & & $\mathbf{P}_{1}$ & $\mathbf{P}_{2}$ & $\mathbf{P}_{3}$ & $\mathbf{P}_{4}$ & $P_{5}$ & & $\mathbf{P}_{1}$ & $\mathbf{P}_{2}$ & $\mathbf{P}_{3}$ & $\mathbf{P}_{4}$ & $\mathbf{P}_{5}$ \\
\hline \multirow{18}{*}{$\mathrm{DM}_{1}$} & $\mathrm{C}_{11}$ & (G, VH) & $(\mathrm{G}, \mathrm{VH})$ & $(\mathrm{VG}, \mathrm{H})$ & $(\mathrm{G}, \mathrm{H})$ & $(\mathrm{G}, \mathrm{VH})$ & \multirow{18}{*}{$\mathrm{DM}_{2}$} & $(\mathrm{G}, \mathrm{H})$ & $(\mathrm{G}, \mathrm{H})$ & $(\mathrm{G}, \mathrm{VH})$ & $(\mathrm{G}, \mathrm{VH})$ & $(\mathrm{G}, \mathrm{H})$ \\
\hline & $\mathrm{C}_{12}$ & $(\mathrm{VG}, \mathrm{N})$ & $(\mathrm{G}, \mathrm{VH})$ & $(\mathrm{G}, \mathrm{VH})$ & $(\mathrm{VG}, \mathrm{N})$ & $(\mathrm{VG}, \mathrm{N})$ & & $(\mathrm{G}, \mathrm{VH})$ & $(\mathrm{G}, \mathrm{H})$ & $(\mathrm{VG}, \mathrm{N})$ & $(\mathrm{G}, \mathrm{H})$ & $(\mathrm{G}, \mathrm{VH})$ \\
\hline & $\mathrm{C}_{13}$ & $(\mathrm{G}, \mathrm{H})$ & $(\mathrm{G}, \mathrm{H})$ & $(\mathrm{G}, \mathrm{H})$ & $(G, V H)$ & $(\mathrm{G}, \mathrm{VH})$ & & $(G, V H)$ & $(\mathrm{G}, \mathrm{H})$ & $(\mathrm{G}, \mathrm{VH})$ & $(\mathrm{G}, \mathrm{H})$ & $(\mathrm{G}, \mathrm{H})$ \\
\hline & $\mathrm{C}_{14}$ & (G, VH) & $(\mathrm{G}, \mathrm{VH})$ & $(\mathrm{VG}, \mathrm{H})$ & $(\mathrm{G}, \mathrm{VH})$ & $(\mathrm{VG}, \mathrm{N})$ & & $(\mathrm{G}, \mathrm{VH})$ & $(\mathrm{G}, \mathrm{VH})$ & $(G, H)$ & $(\mathrm{VG}, \mathrm{H})$ & $(\mathrm{VG}, \mathrm{H})$ \\
\hline & $\mathrm{C}_{21}$ & $(\mathrm{G}, \mathrm{H})$ & $(\mathrm{G}, \mathrm{N})$ & $(\mathrm{G}, \mathrm{H})$ & $(\mathrm{G}, \mathrm{VH})$ & $(\mathrm{G}, \mathrm{H})$ & & $(\mathrm{G}, \mathrm{VH})$ & $(\mathrm{G}, \mathrm{H})$ & $(\mathrm{G}, \mathrm{VH})$ & $(\mathrm{G}, \mathrm{H})$ & $(\mathrm{G}, \mathrm{H})$ \\
\hline & $\mathrm{C}_{22}$ & (G, VH) & $(\mathrm{G}, \mathrm{VH})$ & $(\mathrm{G}, \mathrm{H})$ & $(\mathrm{G}, \mathrm{H})$ & $(\mathrm{G}, \mathrm{VH})$ & & $(\mathrm{G}, \mathrm{H})$ & $(\mathrm{G}, \mathrm{N})$ & $(\mathrm{G}, \mathrm{H})$ & $(\mathrm{G}, \mathrm{VH})$ & $(\mathrm{VG}, \mathrm{N})$ \\
\hline & $\mathrm{C}_{23}$ & $(\mathrm{G}, \mathrm{H})$ & $(\mathrm{G}, \mathrm{N})$ & $(\mathrm{G}, \mathrm{H})$ & $(\mathrm{G}, \mathrm{VH})$ & $(\mathrm{F}, \mathrm{VH})$ & & $(\mathrm{G}, \mathrm{VH})$ & $(\mathrm{G}, \mathrm{H})$ & $(\mathrm{G}, \mathrm{VH})$ & $(\mathrm{G}, \mathrm{H})$ & $(\mathrm{G}, \mathrm{VH})$ \\
\hline & $C_{31}$ & $(\mathrm{G}, \mathrm{VH})$ & $(\mathrm{G}, \mathrm{H})$ & $(\mathrm{G}, \mathrm{VH})$ & $(G, V H)$ & $(\mathrm{G}, \mathrm{H})$ & & $(G, V H)$ & $(\mathrm{G}, \mathrm{H})$ & $(\mathrm{G}, \mathrm{VH})$ & $(\mathrm{G}, \mathrm{VH})$ & $(\mathrm{VG}, \mathrm{H})$ \\
\hline & $\mathrm{C}_{32}$ & $(\mathrm{VG}, \mathrm{H})$ & $(\mathrm{VG}, \mathrm{H})$ & $(\mathrm{G}, \mathrm{VH})$ & $(\mathrm{F}, \mathrm{VH})$ & $(\mathrm{G}, \mathrm{H})$ & & $(\mathrm{VG}, \mathrm{H})$ & $(\mathrm{VG}, \mathrm{H})$ & (VG, VH) & $(\mathrm{G}, \mathrm{VH})$ & $(\mathrm{G}, \mathrm{VH})$ \\
\hline & $\mathrm{C}_{33}$ & $(\mathrm{G}, \mathrm{H})$ & $(\mathrm{G}, \mathrm{VH})$ & $(\mathrm{G}, \mathrm{H})$ & $(\mathrm{G}, \mathrm{H})$ & $(\mathrm{G}, \mathrm{N})$ & & $(\mathrm{G}, \mathrm{H})$ & $(\mathrm{G}, \mathrm{H})$ & $(\mathrm{G}, \mathrm{H})$ & $(\mathrm{G}, \mathrm{N})$ & $(\mathrm{G}, \mathrm{H})$ \\
\hline & $\mathrm{C}_{41}$ & $(\mathrm{G}, \mathrm{VH})$ & $(\mathrm{G}, \mathrm{VH})$ & $(\mathrm{G}, \mathrm{H})$ & $(\mathrm{VG}, \mathrm{N})$ & $(\mathrm{G}, \mathrm{VH})$ & & $(\mathrm{G}, \mathrm{VH})$ & $(\mathrm{G}, \mathrm{VH})$ & $(\mathrm{VG}, \mathrm{N})$ & $(\mathrm{G}, \mathrm{VH})$ & $(\mathrm{G}, \mathrm{H})$ \\
\hline & $\mathrm{C}_{42}$ & $(\mathrm{VG}, \mathrm{H})$ & $(\mathrm{VG}, \mathrm{H})$ & $(\mathrm{VG}, \mathrm{H})$ & $(\mathrm{G}, \mathrm{VH})$ & $(\mathrm{G}, \mathrm{H})$ & & $(\mathrm{VG}, \mathrm{H})$ & $(\mathrm{VG}, \mathrm{H})$ & $(\mathrm{G}, \mathrm{VH})$ & $(\mathrm{VG}, \mathrm{N})$ & $(\mathrm{VG}, \mathrm{H})$ \\
\hline & $\mathrm{C}_{43}$ & $(\mathrm{VG}, \mathrm{H})$ & $(\mathrm{G}, \mathrm{VH})$ & $(\mathrm{G}, \mathrm{VH})$ & $(\mathrm{G}, \mathrm{H})$ & $(\mathrm{G}, \mathrm{H})$ & & $(G, V H)$ & $(\mathrm{G}, \mathrm{H})$ & $(\mathrm{G}, \mathrm{H})$ & $(G, N)$ & $(\mathrm{G}, \mathrm{VH})$ \\
\hline & $\mathrm{C}_{51}$ & $(\mathrm{G}, \mathrm{H})$ & $(\mathrm{G}, \mathrm{VH})$ & $(\mathrm{G}, \mathrm{H})$ & $(G, N)$ & $(\mathrm{F}, \mathrm{VH})$ & & $(\mathrm{G}, \mathrm{VH})$ & $(\mathrm{G}, \mathrm{H})$ & $(\mathrm{G}, \mathrm{VH})$ & $(\mathrm{G}, \mathrm{VH})$ & $(\mathrm{G}, \mathrm{VH})$ \\
\hline & $C_{52}$ & $(\mathrm{G}, \mathrm{VH})$ & $(\mathrm{F}, \mathrm{VH})$ & $(\mathrm{VG}, \mathrm{N})$ & $(\mathrm{G}, \mathrm{H})$ & $(\mathrm{G}, \mathrm{N})$ & & $(\mathrm{VG}, \mathrm{N})$ & $(\mathrm{G}, \mathrm{H})$ & $(\mathrm{G}, \mathrm{H})$ & $(\mathrm{G}, \mathrm{N})$ & $(\mathrm{G}, \mathrm{VH})$ \\
\hline & $\mathrm{C}_{53}$ & $(\mathrm{G}, \mathrm{VH})$ & $(\mathrm{G}, \mathrm{H})$ & $(\mathrm{VG}, \mathrm{H})$ & $(\mathrm{G}, \mathrm{VH})$ & $(\mathrm{VG}, \mathrm{N})$ & & $(\mathrm{G}, \mathrm{VH})$ & $(\mathrm{G}, \mathrm{H})$ & $(\mathrm{VG}, \mathrm{N})$ & $(\mathrm{F}, \mathrm{N})$ & $(\mathrm{G}, \mathrm{VH})$ \\
\hline & $\mathrm{C}_{61}$ & $(\mathrm{G}, \mathrm{H})$ & $(\mathrm{G}, \mathrm{H})$ & $(\mathrm{G}, \mathrm{VH})$ & $(\mathrm{VG}, \mathrm{N})$ & $(\mathrm{G}, \mathrm{H})$ & & $(\mathrm{G}, \mathrm{H})$ & $(\mathrm{G}, \mathrm{H})$ & $(\mathrm{G}, \mathrm{VH})$ & $(G, N)$ & $(\mathrm{VG}, \mathrm{H})$ \\
\hline & $\mathrm{C}_{62}$ & $(\mathrm{VG}, \mathrm{N})$ & $(\mathrm{G}, \mathrm{VH})$ & $(\mathrm{G}, \mathrm{H})$ & $(\mathrm{G}, \mathrm{H})$ & $(\mathrm{G}, \mathrm{H})$ & & $(\mathrm{G}, \mathrm{VH})$ & $(\mathrm{G}, \mathrm{VH})$ & $(\mathrm{G}, \mathrm{H})$ & $(\mathrm{F}, \mathrm{N})$ & $(\mathrm{G}, \mathrm{H})$ \\
\hline \multirow{18}{*}{$\mathrm{DM}_{3}$} & $C_{11}$ & $(\mathrm{G}, \mathrm{H}$ & $(\mathrm{G}, \mathrm{H})$ & $(\mathrm{G}, \mathrm{H})$ & $(\mathrm{G}, \mathrm{H})$ & 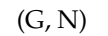 & \multirow{18}{*}{$\mathrm{DM}_{4}$} & $(\mathrm{G}$, & $(\mathrm{G}, \mathrm{I}$ & $(\mathrm{G}, \mathrm{)}$ & (VG & $(\mathrm{G}, \mathrm{VH})$ \\
\hline & $C_{12}$ & $(\mathrm{G}, \mathrm{H})$ & $(G, N)$ & $(G, N)$ & $(\mathrm{F}, \mathrm{VH})$ & $(\mathrm{F}, \mathrm{VH})$ & & $(\mathrm{G}, \mathrm{VH})$ & $(\mathrm{G}, \mathrm{VH})$ & $(\mathrm{VG}, \mathrm{N})$ & $(\mathrm{G}, \mathrm{VH})$ & $(\mathrm{G}, \mathrm{H})$ \\
\hline & $\mathrm{C}_{13}$ & $(\mathrm{~F}, \mathrm{VH})$ & $(\mathrm{F}, \mathrm{H})$ & $(\mathrm{F}, \mathrm{H})$ & $(\mathrm{F}, \mathrm{H})$ & $(\mathrm{F}, \mathrm{H})$ & & $(\mathrm{VG}, \mathrm{H})$ & $(\mathrm{VG}, \mathrm{N})$ & $(\mathrm{G}, \mathrm{VH})$ & $(\mathrm{VG}, \mathrm{N})$ & $(\mathrm{G}, \mathrm{H})$ \\
\hline & $\mathrm{C}_{14}$ & $(G, N)$ & $(\mathrm{G}, \mathrm{H})$ & $(G, N)$ & $(\mathrm{G}, \mathrm{H})$ & $(\mathrm{G}, \mathrm{N})$ & & $(\mathrm{G}, \mathrm{H})$ & $(\mathrm{G}, \mathrm{VH})$ & $(\mathrm{G}, \mathrm{H})$ & $(\mathrm{G}, \mathrm{VH})$ & $(G, H)$ \\
\hline & $\mathrm{C}_{21}$ & $(\mathrm{G}, \mathrm{N})$ & $(\mathrm{G}, \mathrm{H})$ & $(G, N)$ & $(\mathrm{G}, \mathrm{VH})$ & $(\mathrm{G}, \mathrm{N})$ & & $(\mathrm{G}, \mathrm{H})$ & $(\mathrm{F}, \mathrm{VH})$ & $(\mathrm{G}, \mathrm{VH})$ & $(\mathrm{F}, \mathrm{VH})$ & $(\mathrm{G}, \mathrm{H})$ \\
\hline & $\mathrm{C}_{22}$ & $(\mathrm{G}, \mathrm{H})$ & $(\mathrm{G}, \mathrm{H})$ & $(\mathrm{G}, \mathrm{H})$ & $(\mathrm{G}, \mathrm{N})$ & $(\mathrm{G}, \mathrm{N})$ & & $(\mathrm{G}, \mathrm{H})$ & $(\mathrm{G}, \mathrm{VH})$ & $(\mathrm{G}, \mathrm{H})$ & $(\mathrm{G}, \mathrm{VH})$ & $(\mathrm{G}, \mathrm{VH})$ \\
\hline & $\mathrm{C}_{23}$ & $(\mathrm{~F}, \mathrm{H})$ & $(\mathrm{F}, \mathrm{VH})$ & $(\mathrm{F}, \mathrm{H})$ & $(\mathrm{F}, \mathrm{H})$ & $(\mathrm{G}, \mathrm{H})$ & & $(G, N)$ & $(\mathrm{F}, \mathrm{VH})$ & $(\mathrm{G}, \mathrm{VH})$ & $(\mathrm{G}, \mathrm{H})$ & $(\mathrm{G}, \mathrm{N})$ \\
\hline & $\mathrm{C}_{31}$ & $(\mathrm{G}, \mathrm{H})$ & $(\mathrm{G}, \mathrm{H})$ & $(G, N)$ & $(G, N)$ & $(\mathrm{G}, \mathrm{H})$ & & $(\mathrm{G}, \mathrm{VH})$ & $(\mathrm{VG}, \mathrm{N})$ & $(\mathrm{G}, \mathrm{H})$ & $(\mathrm{G}, \mathrm{VH})$ & $(\mathrm{VG}, \mathrm{N})$ \\
\hline & $C_{32}$ & $(\mathrm{G}, \mathrm{N})$ & $(\mathrm{F}, \mathrm{VH})$ & $(\mathrm{G}, \mathrm{N})$ & $(\mathrm{F}, \mathrm{H})$ & $(\mathrm{G}, \mathrm{VH})$ & & $(\mathrm{G}, \mathrm{H})$ & $(\mathrm{G}, \mathrm{H})$ & $(\mathrm{G}, \mathrm{VH})$ & $(\mathrm{G}, \mathrm{VH})$ & $(\mathrm{G}, \mathrm{H})$ \\
\hline & $\mathrm{C}_{33}$ & $(\mathrm{G}, \mathrm{N})$ & $(\mathrm{F}, \mathrm{H})$ & $(\mathrm{G}, \mathrm{H})$ & $(\mathrm{F}, \mathrm{H})$ & $(\mathrm{G}, \mathrm{N})$ & & $(\mathrm{G}, \mathrm{VH})$ & $(\mathrm{VG}, \mathrm{N})$ & $(\mathrm{G}, \mathrm{H})$ & $(\mathrm{G}, \mathrm{VH})$ & $(\mathrm{G}, \mathrm{H})$ \\
\hline & $\mathrm{C}_{41}$ & $(\mathrm{G}, \mathrm{H})$ & $(G, N)$ & $(\mathrm{G}, \mathrm{H})$ & $(G, N)$ & $(\mathrm{G}, \mathrm{N})$ & & $(\mathrm{VG}, \mathrm{H})$ & $(\mathrm{G}, \mathrm{VH})$ & $(\mathrm{G}, \mathrm{VH})$ & $(\mathrm{VG}, \mathrm{N})$ & $(\mathrm{G}, \mathrm{VH})$ \\
\hline & $\mathrm{C}_{42}$ & $(\mathrm{~F}, \mathrm{VH})$ & $(\mathrm{G}, \mathrm{N})$ & $(\mathrm{F}, \mathrm{H})$ & $(\mathrm{G}, \mathrm{H})$ & $(\mathrm{F}, \mathrm{VH})$ & & $(\mathrm{G}, \mathrm{VH})$ & $(\mathrm{G}, \mathrm{VH})$ & $(\mathrm{G}, \mathrm{H})$ & $(\mathrm{G}, \mathrm{VH})$ & $(\mathrm{G}, \mathrm{H})$ \\
\hline & $\mathrm{C}_{43}$ & $(G, N)$ & $(\mathrm{G}, \mathrm{N})$ & $(\mathrm{G}, \mathrm{H})$ & $(\mathrm{G}, \mathrm{H})$ & $(\mathrm{G}, \mathrm{N})$ & & $(\mathrm{G}, \mathrm{H})$ & $(\mathrm{VG}, \mathrm{N})$ & $(\mathrm{G}, \mathrm{VH})$ & $(\mathrm{G}, \mathrm{H})$ & $(\mathrm{G}, \mathrm{VH})$ \\
\hline & $C_{51}$ & $(\mathrm{~F}, \mathrm{H})$ & $(\mathrm{G}, \mathrm{H})$ & $(\mathrm{F}, \mathrm{VH})$ & $(\mathrm{G}, \mathrm{N})$ & $(\mathrm{F}, \mathrm{VH})$ & & $(\mathrm{G}, \mathrm{H})$ & $(\mathrm{G}, \mathrm{VH})$ & $(\mathrm{G}, \mathrm{N})$ & $(\mathrm{G}, \mathrm{VH})$ & $(\mathrm{G}, \mathrm{H})$ \\
\hline & $C_{52}$ & $(\mathrm{G}, \mathrm{N})$ & $(\mathrm{G}, \mathrm{H})$ & $(\mathrm{G}, \mathrm{VH})$ & $(\mathrm{G}, \mathrm{VH})$ & $(\mathrm{G}, \mathrm{N})$ & & $(\mathrm{G}, \mathrm{VH})$ & $(\mathrm{G}, \mathrm{H})$ & $(\mathrm{G}, \mathrm{VH})$ & $(\mathrm{VG}, \mathrm{N})$ & $(\mathrm{G}, \mathrm{VH})$ \\
\hline & $\mathrm{C}_{53}$ & $(\mathrm{G}, \mathrm{N})$ & $(\mathrm{F}, \mathrm{VH})$ & $(\mathrm{F}, \mathrm{VH})$ & $(\mathrm{F}, \mathrm{H})$ & $(\mathrm{F}, \mathrm{H})$ & & $(\mathrm{G}, \mathrm{H})$ & $(\mathrm{F}, \mathrm{VH})$ & $(\mathrm{G}, \mathrm{H})$ & $(\mathrm{G}, \mathrm{VH})$ & $(\mathrm{G}, \mathrm{H})$ \\
\hline & $\mathrm{C}_{61}$ & $(\mathrm{~F}, \mathrm{VH})$ & $(\mathrm{F}, \mathrm{VH})$ & $(\mathrm{F}, \mathrm{H})$ & $(\mathrm{F}, \mathrm{H})$ & $(\mathrm{G}, \mathrm{N})$ & & $(\mathrm{G}, \mathrm{VH})$ & $(\mathrm{G}, \mathrm{H})$ & $(G, N)$ & $(\mathrm{VG}, \mathrm{N})$ & $(\mathrm{G}, \mathrm{VH})$ \\
\hline & $\mathrm{C}_{62}$ & $(\mathrm{G}, \mathrm{H})$ & $(\mathrm{G}, \mathrm{N})$ & $(\mathrm{G}, \mathrm{H})$ & $(\mathrm{F}, \mathrm{VH})$ & $(\mathrm{F}, \mathrm{VH})$ & & $(\mathrm{G}, \mathrm{H})$ & $(\mathrm{G}, \mathrm{VH})$ & $(\mathrm{G}, \mathrm{H})$ & $(G, H)$ & $(\mathrm{G}, \mathrm{H})$ \\
\hline
\end{tabular}

\section{References}

1. Peng, H.; Wang, X.; Wang, T.; Liu, Y.; Wang, J. A Multi-Criteria Decision Support Framework for Inland Nuclear Power Plant Site Selection under Z-Information: A Case Study in Hunan Province of China. Mathematics 2020, 8, 252. [CrossRef]

2. Power Reactor Information System (PRIS). Available online: https://pris.iaea.org/pris/ (accessed on 6 August 2020).

3. Guo, Y.; Wei, Y. Government communication effectiveness on local acceptance of nuclear power: Evidence from China. J. Clean. Prod. 2019, 218, 38-50. [CrossRef]

4. Grover, R.B. The Civil Liability for Nuclear Damage Act of India: An engineering perspective regarding Supplier's liability. Prog. Nucl. Energy 2017, 101, 168-175. [CrossRef]

5. Wang, X.; Wang, Y.; Wang, J.; Cheng, P.; Li, L. A TODIM-PROMETHEE II Based Multi-Criteria Group Decision Making Method for Risk Evaluation of Water Resource Carrying Capacity under Probabilistic Linguistic Z-Number Circumstances. Mathematics 2020, 8, 1190. [CrossRef]

6. Tian, Z.; Nie, R.; Wang, J. Social network analysis-based consensus-supporting framework for large-scale group decision-making with incomplete interval type-2 fuzzy information. Inf. Sci. 2019, 502, 446-471. [CrossRef]

7. Tian, Z.; Zhang, H.; Wang, J.; Wang, T. Green Supplier Selection Using Improved TOPSIS and Best-Worst Method Under Intuitionistic Fuzzy Environment. Informatica 2018, 29, 773-800. (In Lithuan) [CrossRef]

8. Li, J.; Wang, J. An Extended QUALIFLEX Method Under Probability Hesitant Fuzzy Environment for Selecting Green Suppliers. Int. J. Fuzzy Syst. 2017, 19, 1866-1879. [CrossRef]

9. Chen, T.; He, S.; Wang, J.; Li, L.; Luo, H. Novel operations for linguistic neutrosophic sets on the basis of Archimedean copulas and co-copulas and their application in multi-criteria decision-making problems. J. Intell. Fuzzy Syst. 2019, 37, 2887-2912. [CrossRef] 
10. Kannan, D.; Mina, H.; Nosrati-Abarghooee, S.; Khosrojerdi, G. Sustainable circular supplier selection: A novel hybrid approach. Sci. Total Environ. 2020, 722, 137936. [CrossRef]

11. Shen, K.; Wang, J. Z-VIKOR Method Based on a New Comprehensive Weighted Distance Measure of Z-Number and Its Application. IEEE Trans. Fuzzy Syst. 2018, 26, 3232-3245. [CrossRef]

12. Tian, C.; Peng, J.J.; Zhang, Z.Q.; Goh, M.; Wang, J.Q. A Multi-Criteria Decision-Making Method Based on Single-Valued Neutrosophic Partitioned Heronian Mean Operator. Mathematics 2020, 8, 1189. [CrossRef]

13. Xiao, F.; Wang, J. Multistage decision support framework for sites selection of solar power plants with probabilistic linguistic information. J. Clean. Prod. 2019, 230, 1396-1409. [CrossRef]

14. Peng, H.; Wang, J. Multi-criteria sorting decision making based on dominance and opposition relations with probabilistic linguistic information. Fuzzy Optim. Decis. Mak. 2020, in press. [CrossRef]

15. Peng, J.; Tian, C.; Zhang, W.; Zhang, S.; Wang, J. An integrated multi-criteria decision-making framework for sustainable supplier selection under picture fuzzy environment. Technol. Econ. Dev. Econ. 2020, 26, 573-598. [CrossRef]

16. Gore, R.; Reynolds, P.F.J.; Kamensky, D.; Diallo, S.; Padilla, J. Statistical Debugging for Simulations. Acm. Trans. Model. Comput. Simul. 2015, 25, 1-26. [CrossRef]

17. Kacprzyk, J.; Fedrizzi, M.; Nurmi, H. Group decision making and consensus under fuzzy preferences and fuzzy majority. Fuzzy Set. Syst. 1992, 49, 21-31. [CrossRef]

18. Bates, J.H.T.; Young, M.P. Applying Fuzzy Logic to Medical Decision Making in the Intensive Care Unit. Am. J. Respir. Crit. Care Med. 2003, 167, 948-952. [CrossRef]

19. Peng, H.; Zhang, H.; Wang, J.; Li, L. An uncertain Z-number multicriteria group decision-making method with cloud models. Inf. Sci. 2019, 501, 136-154. [CrossRef]

20. Qiao, D.; Shen, K.; Wang, J.; Wang, T. Multi-criteria PROMETHEE method based on possibility degree with Z-numbers under uncertain linguistic environment. J. Ambient Intell. Humaniz. Comput. 2020, 11, 2187-2201. [CrossRef]

21. Zadeh, L.A. A Note on Z-numbers. Inf. Sci. 2011, 181, 2923-2932. [CrossRef]

22. Song, C.; Wang, J.; Li, J. New Framework for Quality Function Deployment Using Linguistic Z-Numbers. Mathematics 2020, 8, 224. [CrossRef]

23. Shen, K.; Wang, X.; Qiao, D.; Wang, J. Extended Z-MABAC method based on regret theory and directed distance for regional circular economy development program selection with Z-information. IEEE Trans. Fuzzy Syst. 2019, 28, 1851-1863. [CrossRef]

24. Jiang, S.; Shi, H.; Lin, W.; Liu, H. A large group linguistic Z-DEMATEL approach for identifying key performance indicators in hospital performance management. Appl. Soft Comput. 2020, 86, 105900. [CrossRef]

25. Saaty, T.L. Decision Making with Dependence and Feedback: The Analytic Network Process; RWS Publications: Pittsburgh, PA, USA, 1996; Volume 95, pp. 129-157.

26. Wu, Y.; Zhang, B.; Xu, C.; Li, L. Site selection decision framework using fuzzy ANP-VIKOR for large commercial rooftop PV system based on sustainability perspective. Sustain. Cities Soc. 2018, 40, 454-470. [CrossRef]

27. Zhang, G.; Wang, J.Q.; Wang, T.L. Multi-criteria group decision-making method based on TODIM with probabilistic interval-valued hesitant fuzzy information. Expert Syst. 2019, 36, e12424. [CrossRef]

28. Kiani Mavi, R.; Standing, C. Critical success factors of sustainable project management in construction: A fuzzy DEMATEL-ANP approach. J. Clean. Prod. 2018, 194, 751-765. [CrossRef]

29. Tian, C.; Peng, J. An integrated picture fuzzy anp-todim multi-criteria decision-making approach for tourism attraction recommendation. Technol. Econ. Dev. Econ. 2020, 26, 331-354. [CrossRef]

30. Mistarihi, M.Z.; Okour, R.A.; Mumani, A.A. An integration of a QFD model with Fuzzy-ANP approach for determining the importance weights for engineering characteristics of the proposed wheelchair design. Appl. Soft Comput. 2020, 90, 106136. [CrossRef]

31. Gomes, L.F.A.M.; Rangel, L.A.D.; Maranhão, F.J.C. Multicriteria analysis of natural gas destination in Brazil: An application of the TODIM method. Math. Comput. Model. 2009, 50, 92-100. [CrossRef]

32. Wang, L.; Wang, Y.; Martínez, L. Fuzzy TODIM method based on alpha-level sets. Expert Syst. Appl. 2020, 140, 112899. [CrossRef]

33. Yu, S.; Wang, J.; Wang, J. An extended TODIM approach with intuitionistic linguistic numbers. Int. Trans. Oper. Res. 2018, 25, 781-805. [CrossRef] 
34. Zhu, J.; Shuai, B.; Wang, R.; Chin, K. Risk Assessment for Failure Mode and Effects Analysis Using the Bonferroni Mean and TODIM Method. Mathematics 2019, 7, 536. [CrossRef]

35. Alali, F.; Tolga, A.C. Portfolio allocation with the TODIM method. Expert Syst. Appl. 2019, 124, 341-348. [CrossRef]

36. Krohling, R.A.; de Souza, T.T.M. Combining prospect theory and fuzzy numbers to multi-criteria decision making. Expert Syst. Appl. 2012, 39, 11487-11493. [CrossRef]

37. Krohling, R.A.; Santos, A.D.; Pacheco, A.G.C. TODIM and TOPSIS with Z-numbers. Front. Inf. Tech. Electron. Eng. 2019, 20, 283-291. [CrossRef]

38. Yang, G.; Huang, W.J.; Lei, L.L. Using AHP and TOPSIS Approaches in Nuclear Power Plant Equipment Supplier Selection. Key Eng. Mater. 2010, 419-420, 761-764. [CrossRef]

39. Wu, Y.; Chen, K.; Zeng, B.; Xu, H.; Yang, Y. Supplier selection in nuclear power industry with extended VIKOR method under linguistic information. Appl. Soft Comput. 2016, 48, 444-457. [CrossRef]

40. Phochanikorn, P.; Tan, C. A New Extension to a Multi-Criteria Decision-Making Model for Sustainable Supplier Selection under an Intuitionistic Fuzzy Environment. Sustainability 2019, 11, 5413. [CrossRef]

41. Liu, P.C.Y.; Lo, H.; Liou, J.J.H. A Combination of DEMATEL and BWM-Based ANP Methods for Exploring the Green Building Rating System in Taiwan. Sustainability 2020, 12, 3216. [CrossRef]

42. Giannakis, M.; Dubey, R.; Vlachos, I.; Ju, Y. Supplier sustainability performance evaluation using the analytic network process. J. Clean. Prod. 2020, 247, 119439. [CrossRef]

43. Guang, Y.; Wenjie, H. Application of the TOPSIS Based on Entropy-AHP Weight in Nuclear Power Plant Nuclear-Grade Equipment Supplier Selection. In Proceedings of the International Conference on Environmental Science and Information Application Technology, Wuhan, China, 4-5 July 2009; pp. 633-636.

44. Wu, X.; Wang, J.; Peng, J.; Chen, X. Cross-Entropy and Prioritized Aggregation Operator with Simplified Neutrosophic Sets and Their Application in Multi-Criteria Decision-Making Problems. Int. J. Fuzzy Syst. 2016, 18, 1104-1116. [CrossRef]

45. Nie, R.; Tian, Z.; Wang, J.; Chin, K.S. Hotel selection driven by online textual reviews: Applying a semantic partitioned sentiment dictionary and evidence theory. Int. J. Hosp. Manag. 2020, 88, 102495. [CrossRef]

46. Liang, R.; Wang, J.; Zhang, H. A multi-criteria decision-making method based on single-valued trapezoidal neutrosophic preference relations with complete weight information. Neural Comput. Appl. 2018, 30, 3383-3398. [CrossRef]

47. Shen, K.; Li, L.; Wang, J. Circular economy model for recycling waste resources under government participation: A case study in industrial waste water circulation in china. Technol. Econ. Dev. Econ. 2020, 26, 21-47. [CrossRef]

48. Deng, X.; Hu, Y.; Deng, Y.; Mahadevan, S. Supplier selection using AHP methodology extended by D numbers. Expert Syst. Appl. 2014, 41, 156-167. [CrossRef]

49. Forghani, A.; Sadjadi, S.J.; Farhang Moghadam, B. A supplier selection model in pharmaceutical supply chain using PCA, Z-TOPSIS and MILP: A case study. PLoS ONE 2018, 13, 201604. [CrossRef]

50. Rezaei, J.; Nispeling, T.; Sarkis, J.; Tavasszy, L. A supplier selection life cycle approach integrating traditional and environmental criteria using the best worst method. J. Clean. Prod. 2016, 135, 577-588. [CrossRef]

51. Lootsma Freerk, A. Fuzzy Logic for Planning and Decision Making; Springer Science \& Business Media: Boston, MA, USA, 1997.

52. Kang, B.; Wei, D.; Li, Y.; Deng, Y. A method of converting Z-number to classical fuzzy number. J. Inf. Comput. Sci. 2012, 9, 703-709.

53. Kahraman, C.; Ertay, T.; Büyüközkan, G. A fuzzy optimization model for QFD planning process using analytic network approach. Eur. J. Oper. Res. 2006, 171, 390-411. [CrossRef]

54. Chen, Z.Y.; Wang, X.K.; Peng, J.J.; Zhang, H.Y.; Wang, J.Q. An integrated probabilistic linguistic projection method for MCGDM based on ELECTRE III and the weighted convex median voting rule. Expert Syst. 2020, in press. [CrossRef]

55. Kahneman, D.; Tversky, A. Prospect Theory: An Analysis of Decision under Risk. Econometrica 1979, 47, 263-291. [CrossRef] 
56. Wang, B.; Xie, H.; Ren, H.; Li, X.; Chen, L.; Wu, B. Application of AHP, TOPSIS, and TFNs to plant selection for phytoremediation of petroleum-contaminated soils in shale gas and oil fields. J. Clean. Prod. 2019, 233, 13-22. [CrossRef]

57. Pamučar, D.; Gigović, L.; Bajić, Z.; Janošević, M. Location Selection for Wind Farms Using GIS Multi-Criteria Hybrid Model: An Approach Based on Fuzzy and Rough Numbers. Sustainability 2017, 9, 1315. [CrossRef]

(C) 2020 by the authors. Licensee MDPI, Basel, Switzerland. This article is an open access article distributed under the terms and conditions of the Creative Commons Attribution (CC BY) license (http://creativecommons.org/licenses/by/4.0/). 